This document is confidential and is proprietary to the American Chemical Society and its authors. Do not copy or disclose without written permission. If you have received this item in error, notify the sender and delete all copies.

\title{
Modeling and numerical investigation of the performance of gas diffusion electrodes for the electrochemical reduction of carbon dioxide to methanol
}

\begin{tabular}{|r|l|}
\hline Journal: & Industrial \& Engineering Chemistry Research \\
\hline Manuscript ID & ie-2020-02358q \\
\hline Manuscript Type: & Article \\
\hline Author: & 09-May-2020 \\
\hline Complete List of Authors: & $\begin{array}{l}\text { El-Shafie, Omnia; Cairo University Faculty of Engineering, Chemical } \\
\text { Engineering Department } \\
\text { El-Maghraby, Rehab; Suez University, Faculty of Petroleum and Mining } \\
\text { Engineering, Petroleum Refinery and Petrochemical Engineering } \\
\text { Department; Suez University, cOil and Green Chemistry Research Centre } \\
\text { / Enhanced Oil Recovery Laboratory } \\
\text { Albo, Jonathan; Universidad de Cantabria, Chemical and Biomolecular } \\
\text { Engineering } \\
\text { Fateen, Seif-Eddeen ; Zewail City of Science and Technology, } \\
\text { Environmental Engineering Program; Cairo University Faculty of } \\
\text { Engineering, Chemical Engineering Department } \\
\text { Abdelghany, Amr; Cairo University Faculty of Engineering, Chemical } \\
\text { Engineering Department }\end{array}$ \\
\hline
\end{tabular}

\section{SCHOLARONE ${ }^{m}$ Manuscripts}




\title{
Modeling and numerical investigation of the
}

\author{
performance of gas diffusion electrodes for the
}

electrochemical reduction of carbon dioxide to

\author{
methanol
}

Omnia A. El-Shafie *a, Rehab M. El-Maghraby ${ }^{b, c}$, Jonathan Albo d, Seif-Eddeen K.

Fateen $^{a, e}$ and Amr Abdelghany ${ }^{a}$.

${ }^{a}$ Chemical Engineering Department, Faculty of Engineering, Cairo University, 12613

Giza, Egypt E-mail: omniaelshafie737@gmail.com

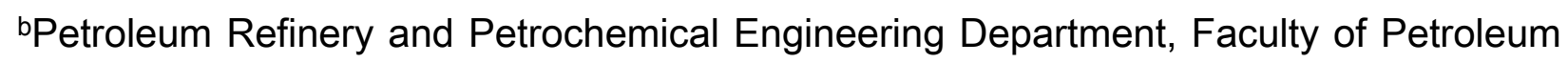

and Mining Engineering, Suez University, Suez, Egypt

'Oil and Green Chemistry Research Centre / Enhanced Oil Recovery Laboratory, Suez

University, Suez, Egypt 


\author{
${ }^{\mathrm{d} D e p a r t m e n t}$ of Chemical \& Biomolecular Engineering, University of Cantabria, 39005 \\ Santander, Spain \\ eEnvironmental Engineering Program, Zewail City of Science and Technology, 12588 \\ Giza, Egypt
}

KEYWORDS: Electrochemical reduction, Carbon Dioxide utilization, Gas Diffusion Electrodes, $\mathrm{CO}_{2}$ conversion, Methanol production.

\begin{abstract}
In this study, a model was built to investigate the role of $\mathrm{Cu}_{2} \mathrm{O}-\mathrm{ZnO}$ based gas diffusion electrodes in enhancing the reduction of carbon dioxide into methanol inside an electrochemical cell. The model was simulated using COMSOL Multiphysics software and validated using experimental results. It showed reasonable agreement with an average error of $6 \%$. The model demonstrated the dependence of methanol production rate and faradaic efficiency on process key variables; current density $\left(j=5-10 \mathrm{~mA} / \mathrm{cm}^{2}\right)$, gas flow
\end{abstract}


rate $\left(Q_{g} / A=10-20 \mathrm{ml} / \mathrm{min} \mathrm{cm}^{2}\right)$, electrolyte flow rate and $\mathrm{CO}_{2}$ gas feed concentration. The results showed a maximum methanol production rate of $50 \mu \mathrm{mol} / \mathrm{m}^{2} \mathrm{~s}$, and faradaic efficiency of $56 \%$ at $-1.38 \mathrm{~V}$ vs. $\mathrm{Ag} / \mathrm{AgCl}$. From the economic point of view, it is recommended to use a gas stream of $90 \%$ or slightly lower $\mathrm{CO}_{2}$ concentration and an

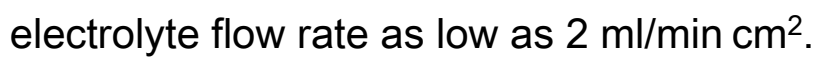

\section{Introduction}


Anthropogenic carbon dioxide $\left(\mathrm{CO}_{2}\right)$ emissions to the atmosphere are reaching an alerting level. ${ }^{1}$ Rapid actions need to be implemented in order to limit such increase and find alternative routes to utilize $\mathrm{CO}_{2} \cdot{ }^{2} \mathrm{CO}_{2}$ valorization is taking more interest nowadays as a way through which captured $\mathrm{CO}_{2}$ is utilized to more valuable products and chemicals. The electrochemical reduction of $\mathrm{CO}_{2}$ has been proposed as a potential option for $\mathrm{CO}_{2}$ valorization. Through this simple electrochemical reduction process, a carbon-neutral energy route will be established where $\mathrm{CO}_{2}$ could be converted to synthesis gas, formaldehyde, different types of alcohols and other valuable products. Despite being a simple process of high potentials ${ }^{1,3-7}$, some challenges ${ }^{1,3,8,9}$ are hindering its industrial application. One of those challenges is the low $\mathrm{CO}_{2}$ solubility in aqueous solution $(0.033$ $\mathrm{mol} / \mathrm{l}$ at STP) ${ }^{3}$, that affects the mass-transfer of $\mathrm{CO}_{2}$ into the aqueous phase and limits the selectivity at high current densities. Some techniques ${ }^{3}$ were proposed to overcome such limitations, which include; lowering the operating temperature ${ }^{10}$, increasing the $\mathrm{CO}_{2}$ partial pressure ${ }^{11,12}$ and using non-aqueous solutions ${ }^{13}$ or solid polymer electrolytes $(\mathrm{SPE})^{14-16}$. The most promising option to overcome such mass transfer limitations is to 
use gas diffusion electrodes (GDEs) ${ }^{17-20}$ where the reacting $\mathrm{CO}_{2}$ could be introduced to the cell directly in the gas phase, resulting in an improvement in the cell performance.

The gas diffusion electrode consists of two layers; the gas diffusion layer (GDL), referred to as diffusion medium, and the catalyst layer $(\mathrm{CL}) \cdot{ }^{21}$ The GDL is usually placed between the $C L$ and the gas channel, and is typically made from carbon-based materials ${ }^{22}$ to maintain high electric conductivity, gas permeability, and stability over a wide potential range. ${ }^{22}$ The GDL is in direct contact with the gas channel where it acts as a gas distributor and current collector. In most cases, the GDL is of a hydrophobic nature to prevent water flooding through the electrode which facilitates reactant gas transportation to the CL. ${ }^{21}$ The GDE improves the electrochemical cell performance by enhancing the catalyst stability, it provides the necessary mechanical support and conducts electrons through its solid phase at low resistance. According to the literature ${ }^{23-25}$, the main advantage of the GDE is the ability to provide a three-phase interface between the solid catalyst particles, the gaseous reacting $\mathrm{CO}_{2}$, and the liquid electrolyte solution. This will increase the active surface area of the electrocatalyst available for the reduction reaction. Despite that the exact pathway for the electrochemical reduction of $\mathrm{CO}_{2}$ in a three-phase 
interface medium is still unknown ${ }^{26}$, it is hypothesized that only gaseous $\mathrm{CO}_{2}$ is involved in the reduction reaction ${ }^{23-25}$. However, other researchers, for example, Weng et al. ${ }^{18}$ opposed this hypothesis and believe that $\mathrm{CO}_{2}$ needs to dissolve first in the aqueous solution for the reduction reaction to occur. Still more investigation is needed, so, in the present study, the nature of the reduction reaction is looked at.

Many experimental studies on the electrochemical reduction of $\mathrm{CO}_{2}$ to carbon monoxide $(\mathrm{CO})^{27,28}$ and formic acid ${ }^{28-30}$ could be found in literature. However, limited experimental data is available on the electrochemical conversion of $\mathrm{CO}_{2}$ to alcohol ${ }^{6,31-37}$. The compilation of experimental data and integration with modeling studies is an essential step in order to facilitate the upscaling of the electrochemical reduction of $\mathrm{CO}_{2}$ into the industrial scale. According to the literature, and as far as the authors know, only one study, conducted by Yosra et. al., $2017^{38}$ investigated the electrochemical reduction of $\mathrm{CO}_{2}$ to methanol $\left(\mathrm{CH}_{3} \mathrm{OH}\right)$. Yosra et. al., $2017^{38}$ developed a mathematical model for the reduction of $\mathrm{CO}_{2}$ into $\mathrm{CH}_{3} \mathrm{OH}$ by using a planner type $\mathrm{Cu}_{2} \mathrm{O} / \mathrm{ZnO}$-based electrode in an aqueous solution of $\mathrm{KHCO}_{3}$. No GDE was used in this study or other studies to model the conversion of $\mathrm{CO}_{2}$ into $\mathrm{CH}_{3} \mathrm{OH}$. However, the work of Yosra et. al., $2017^{38}$ has paved the 
way for further developments in the modeling of the electrochemical cell to convert $\mathrm{CO}_{2}$ into $\mathrm{CH}_{3} \mathrm{OH}$. The current study is considered an advanced step towards the introduction of the GDE in the electrochemical reduction of $\mathrm{CO}_{2}$ to $\mathrm{CH}_{3} \mathrm{OH}$ and ethanol $\left(\mathrm{C}_{2} \mathrm{H}_{5} \mathrm{OH}\right)$. Modeling GDE in the electrochemical conversion of $\mathrm{CO}_{2}$ to different products was investigated by a limited number of researchers. This was listed in Table 1 and compared to the present study.

Table 1. Comparison of literature modeling studies done for $\mathrm{CO}_{2}$ electrochemical reduction on GDE-based electrodes

\begin{tabular}{|c|c|c|c|c|c|c|}
\hline Reference & $\begin{array}{l}\text { Cathodic } \\
\text { Catalyst }\end{array}$ & $\begin{array}{l}\text { Main } \\
\text { Product }\end{array}$ & $\begin{array}{l}\text { Model } \\
\text { Dimensions }\end{array}$ & $\begin{array}{l}\mathrm{CL} \\
\text { modeled } \\
\text { as }\end{array}$ & $\begin{array}{l}\text { Acid-base } \\
\text { Reactions }\end{array}$ & $\begin{array}{l}\text { Phase } \\
\text { Flow }\end{array}$ \\
\hline Wu et. al. ${ }^{24}$ & $\mathrm{Pt}$ & $\mathrm{CO}$ & $2 \mathrm{D}$ & Interface & N.C & Single \\
\hline $\begin{array}{l}\text { Georgopoulou et. } \\
\text { al. }{ }^{39}\end{array}$ & Sn & Formate & $2 \mathrm{D}$ & Interface & C & Two \\
\hline Weng et. al. ${ }^{18}$ & $\mathrm{Ag}$ & $\mathrm{CO}$ & $1 \mathrm{D}$ & Domain & C & Single \\
\hline Present model & $\mathrm{Cu}_{2} \mathrm{O}-\mathrm{ZnO}$ & $\mathrm{CH}_{3} \mathrm{OH}$ & $2 \mathrm{D}$ & Domain & C & Single \\
\hline
\end{tabular}

Wu et. al., $2015^{24}$ developed a model for the production of CO using Pt-based GDE. In their study, they investigated the operating and design parameters effect on process 
performance. However, in the modeled electrochemical cell the produced $\mathrm{CO}$ exits the gas channel together with the unreacted $\mathrm{CO}_{2}$, hence, the probability of $\mathrm{CO}$ interrupting the electrolyte flow (i.e., leading to a two-phase flow) is low. In addition, their model neglected the acid-base reactions occurring inside the electrolyte although such reactions affect the reacting $\mathrm{CO}_{2}$ concentration and its solubility in the electrolyte.

Georgopoulou et. al., $2016^{39}$ developed a model for the electrochemical reduction of $\mathrm{CO}_{2}$ into formic acid using GDE. As the case with Wu et. al.,2015 24 , in their model the products exit the gas channel together with the unreacted $\mathrm{CO}_{2}$ while the formic acid is produced in the aqueous phase, thus their model is considered a two-phase flow. On the other hand, Weng et al.,2019 ${ }^{18}$ treated the CL in their model, to produce CO, as a domain not as an interface like other researchers. ${ }^{24,39}$ Also, they introduced the concept of ideal saturated $C L$ to their model, which refers to the fraction of the catalyst pore volume occupied by liquid electrolyte. According to the literature, no work was conducted to investigate the GDE in the electrochemical reduction of $\mathrm{CO}_{2}$ into $\mathrm{CH}_{3} \mathrm{OH}$, so, more work is needed. 
In this study, a mathematical model was developed and validated for the continuous electrochemical reduction of $\mathrm{CO}_{2}$ to $\mathrm{CH}_{3} \mathrm{OH}$; using $\mathrm{GDE}$, given the high demand and the importance of $\mathrm{CH}_{3} \mathrm{OH}$ and $\mathrm{C}_{2} \mathrm{H}_{5} \mathrm{OH}$ for many chemical and petrochemical industries ${ }^{6,7}$. This work presents a 2D (two-dimensional), steady-state, isothermal model for a continuous filter-press electrochemical cell. The model was simulated using the commercial software COMSOL V5.2. Modified forms of Butler-Volmer equations have been used for expressing the process kinetics. In many cases in the literature, the exchange current density; representing current at thermodynamic equilibrium, is taken as a constant value for each specific reaction and calculated as a fitting parameter, despite being dependant on process conditions, catalyst structure, and particle size..$^{3,40}$ In this work, the exchange current density was related to the flow rates and applied current density through an empirical equation. This model focuses on the mathematical relations describing the effect of using the GDEs to overcome the $\mathrm{CO}_{2}$ mass transfer limits and to increase the production rate. To achieve this goal, the model incorporated charge, mass and momentum transport with electrode kinetics. 


\section{Experimental Equipment and Conditions}

\subsection{Materials and Equipment}

The $\mathrm{Cu}_{2} \mathrm{O} / \mathrm{ZnO}$-based GDEs were prepared according to a procedure previously reported. ${ }^{32,33} \mathrm{Cu}_{2} \mathrm{O}$ (Sigma Aldrich, particle size $<5 \mu \mathrm{m}, 97 \%$ purity) and $\mathrm{ZnO}$ particles (ACROS organic, $<45 \mu \mathrm{m}, 99.5 \%$ ) were mixed with a Nafion® dispersion 5 wt.\% (Alfa Aesar) and isopropanol (IPA) (Sigma Aldrich), with a 70/30 catalyst/Nafion mass ratio and a $3 \%$ solids (catalyst + Nafion). The prepared $\mathrm{Cu}_{2} \mathrm{O} / \mathrm{ZnO}$ inks were airbrushed onto carbon papers (TGP-H-60, Toray Inc.) and then, rinsed with deionized water and dried at

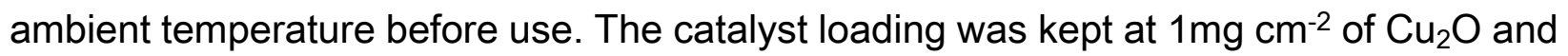
$1 \mathrm{mg} \mathrm{cm}^{-2}$ of $\mathrm{ZnO}$.

\subsection{Methodology}


The experimental setup components, shown in Fig. 1.a is fully detailed in the works of Albo. et al. ${ }^{32,33}$ In summary, $\mathrm{CO}_{2}$ electrochemical reaction was carried out at ambient conditions using a filter-press electrochemical cell (Micro Flow Cell, ElectroCell A/S) in continuous operation. The cell, shown in Fig. $1 . b^{17}$, was divided into a catholyte and anolyte compartments separated by a Nafion 117 membrane. The airbrushed $\mathrm{Cu}_{2} \mathrm{O} / \mathrm{ZnO}-$ catalyzed paper was employed as the working electrodes (geometric area, $A=10 \mathrm{~cm}^{-2}$ ), together with a platinized titanium plate used as the counter electrode and a $\mathrm{Ag} / \mathrm{AgCl}$ (sat. $\mathrm{KCl}$ ) reference electrode. A $0.5 \mathrm{M} \mathrm{KHCO} 3$ (Panreac, > 97\% purity) aqueous solution is pumped at a flow rate of $Q_{\mathrm{e}} / \mathrm{A}=2 \mathrm{ml} \mathrm{min}^{-1} \mathrm{~cm}^{-2}$ in both, the cathode and anode compartments. Besides, $\mathrm{CO}_{2}$ gas $(99.99 \%)$ was fed to the cathode side with a flow rate ranging from $Q_{g} / A=10$ to $20 \mathrm{ml} \mathrm{min}{ }^{-1} \mathrm{~cm}^{-2}$. In addition, the applied current density, $j$, was varied from 5 to $10 \mathrm{~mA} \mathrm{~cm}^{-2}$. To quantify the concentration of each product in the liquid phase, the samples were analysed by duplicate in a headspace gas chromatograph (GCMS-QP2010, Ultra Shimadzu) equipped with a flame ionization detector (FID). The formation rates and faradaic efficiencies are then calculated. 
(a)

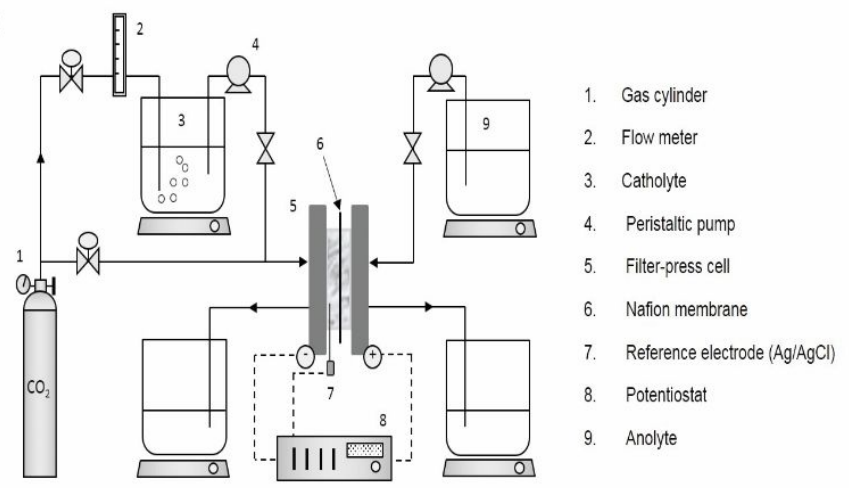

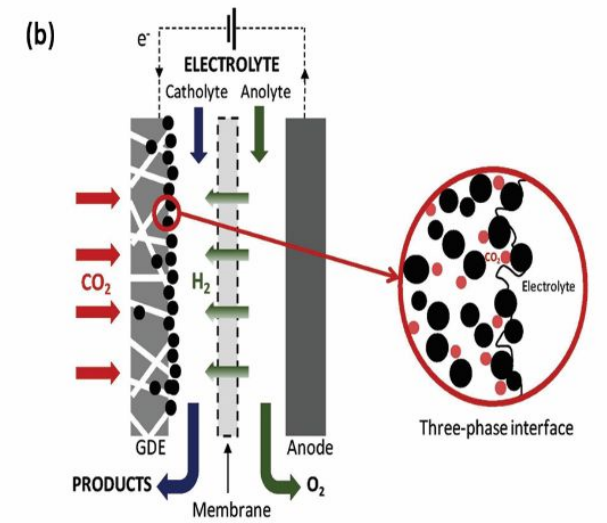

Fig. 1. (a) Experimental setup; (b) Schematic diagram of the electrolytic cell configuration of $\mathrm{CO}_{2}$ electrochemical reduction on $\mathrm{Cu}_{2} \mathrm{O}-\mathrm{ZnO}$ based $\mathrm{GDE}^{17}$

\section{Model Development}

\subsection{Computational Domain}

The domains of the present work are shown in Fig. 2. For simplification, the current collectors and the cathode gas channel were excluded. The electrolyte stream enters the cell via two channels (catholyte and anolyte). The catholyte flows through the porous catalyst layer, at which the catholyte meets the gaseous $\mathrm{CO}_{2}$ stream flowing from the cathode gas channel through the GDL into the catalyst layer. Finally, the electrolyte, products and unreacted materials leave the cell through the catholyte and anolyte outlets. 
The key input parameters used in the model are listed in Table 2. The assumed properties of catalyst layer in Table 2 are based on common values from the literature..$^{21,41,42}$

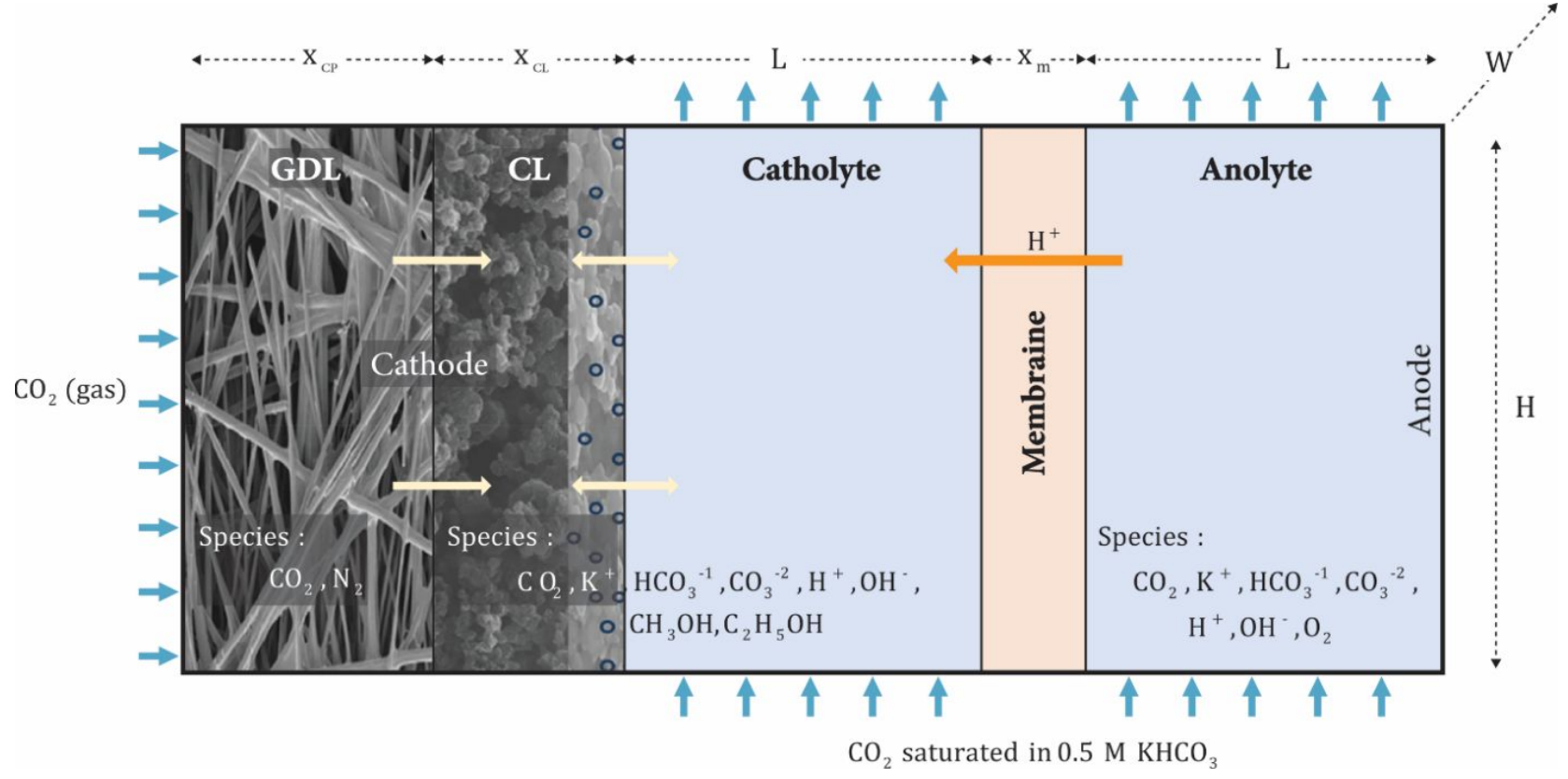

Fig. 2. Schematic diagram of the computational domain used in the present model.

\subsection{Model Assumptions}

The following were assumed in the present work:

- The system is steady-state. ${ }^{24,38}$

- The system is isothermal, i.e., the temperature distribution across the cell is uniform..$^{24,38}$

- Gas flow is considered to be compressible and laminar. 
- Liquid flow is laminar. ${ }^{38}$

- Produced oxygen will completely dissolve in the electrolyte.

- The model is considered as a single-phase flow.

- The physical properties of the electrode are isotropic and homogeneous. ${ }^{42}$

- No-slip boundary condition is applied to all walls and continuity is maintained at electrolyte/porous media interface.

- Dilute theory is applied to the catholyte and anolyte.

- Proton transport from anode to cathode through the membrane is by electro-migration only.

- Convection through the catalyst layer is neglected and species are transported by diffusion and migration only.

- The carbon paper serving as the gas diffusion layer is considered hydrophobic. ${ }^{43}$

- Saturation through the catalyst layer is constant.

Table 2. Model parameters (see nomenclature for symbol definitions) 


\begin{tabular}{llll}
\hline Parameter & Value & Unit & Ref. \\
\hline \multicolumn{2}{c}{ Cell Dimensions } & & \\
$A$ & 10 & $\mathrm{~cm}^{2}$ & 33 \\
$H$ & 33.3 & $\mathrm{~mm}$ & 33 \\
$w$ & 30 & $\mathrm{~mm}$ & 33 \\
$L$ & 4 & $\mathrm{~mm}$ & 38 \\
$x_{m}$ & 0.183 & $\mathrm{~mm}$ & 33 \\
$x_{c p}$ & 0.19 & $\mathrm{~mm}$ & 44 \\
$x_{C L}$ & 0.02 & $\mathrm{~mm}$ & $\begin{array}{l}\text { Approximate } \\
\end{array}$ \\
& & & $\mathrm{d}$
\end{tabular}

\section{Operating Conditions}

$\begin{array}{llll}T & 25 & & \\ & & \mathrm{C} & 33 \\ P & 1 & \mathrm{Bar} & 33 \\ j_{a p p} & 10 & \mathrm{~mA} \mathrm{~cm}-2 & 33 \\ \varphi_{c} & -1.16 & \mathrm{~V} & 33 \\ \varphi_{a} & 1.03 & \mathrm{~V} & 33 \\ Q_{e} / A & 2 & \mathrm{ml} \mathrm{min}^{-1} \mathrm{~cm}^{-2} & 33 \\ Q_{g} / A & 20 & \mathrm{ml} \mathrm{min}^{-1} \mathrm{~cm}^{-2} & 33\end{array}$

\section{Membrane Properties}

\begin{tabular}{llll}
$\sigma_{l, m}$ & 10 & $\mathrm{~S} \mathrm{~m}^{-1}$ & 45 \\
$c_{H^{+}, m}$ & 1200 & $\mathrm{~mol} \mathrm{~m}^{-3}$ & 45 \\
\hline
\end{tabular}




\begin{tabular}{|c|c|c|c|}
\hline Parameter & Value & Unit & Ref. \\
\hline \multicolumn{4}{|c|}{ Carbon Paper Properties } \\
\hline$\varepsilon_{c p}$ & 0.631 & 0.631 & 44 \\
\hline$K_{c p}$ & $\begin{array}{l}6.15 \times 10^{-} \\
12\end{array}$ & $\mathrm{~m}^{2}$ & 44 \\
\hline$\sigma_{c p}$ & $1.053 \times 10^{4}$ & $S \mathrm{~m}^{-1}$ & 44 \\
\hline \multicolumn{4}{|c|}{ Catalyst Layer Properties } \\
\hline$K_{C L}$ & $\begin{array}{l}1.58 \times 10^{-} \\
14\end{array}$ & $m^{2}$ & Assumption \\
\hline$\varepsilon_{c L}$ & 0.4 & & Assumption \\
\hline$x_{C L}$ & 0.02 & $\mathrm{~mm}$ & Assumption \\
\hline$r_{p}$ & 4 & $\mu \mathrm{m}$ & 33 \\
\hline$\sigma_{c L}$ & $10^{-5}$ & $S \mathrm{~m}^{-1}$ & Assumption \\
\hline$\delta_{T f}$ & 10 & $\mathrm{~nm}$ & 21 \\
\hline$s_{C L}$ & 0.5 & & Assumption \\
\hline
\end{tabular}

\section{Gas Properties}

$\begin{array}{lll}M_{\mathrm{CO}_{2}} & 44.009 & \mathrm{Kg} \mathrm{mol}^{-1} \\ M_{N_{2}} & 28.0134 & \mathrm{Kg} \mathrm{mol}^{-1} \\ \rho_{\mathrm{CO}_{2}} & 1.98 & \mathrm{~kg} \mathrm{~m}^{-3} \\ \mu_{\mathrm{CO}_{2}} & 1.5 \times 10^{-5} & \mathrm{~Pa} \mathrm{~s} \\ \mathrm{H}_{\mathrm{CO}_{2}} & 3.3 \times 10^{-4} & \mathrm{~mol} \mathrm{~m}^{-3} \mathrm{~Pa}^{-1}\end{array}$




\begin{tabular}{llcc}
\hline Parameter & Value & Unit & Ref. \\
\hline$v_{\mathrm{CO}_{2}}$ & 26.9 & 46 \\
$v_{N_{2}}$ & 17.9 & 46 \\
$Y_{\mathrm{CO}_{2}, \text { in }}$ & 0.9999 & 33
\end{tabular}

Liquid Electrolyte Properties

$\begin{array}{lll}\rho_{\mathrm{H}_{2} \mathrm{O}} & 10^{3} & \mathrm{~kg} \mathrm{~m}^{-3} \\ \mu_{\mathrm{H}_{2} \mathrm{O}} & 8.9 \times 10^{-4} & \mathrm{~Pa} \mathrm{~s}\end{array}$

Equilibrium Constants

\begin{tabular}{llll}
$K_{2}$ & 4.66 & $\mathrm{~m}^{3} / \mathrm{mol}$ & 38 \\
$K_{3}$ & $4.44 \times 10^{-4}$ & $\mathrm{~mol} / \mathrm{m}^{3}$ & 38 \\
$K_{w}$ & $10^{8}$ & $\mathrm{~m}^{6} / \mathrm{mol}^{2}$ & 38 \\
\hline
\end{tabular}

\subsection{Bulk solution equilibrium}

When gaseous $\mathrm{CO}_{2}$ comes in contact with aqueous solution, $\mathrm{CO}_{2}$ starts to dissolve in the solution as hydrated $\mathrm{CO}_{2}$ (aq) according to eq (1). $\mathrm{CO}_{2}$ in its dissolved form can react with water in a later step as in eqs (2) and (3). ${ }^{47}$

$$
\mathrm{CO}_{2(g)} \leftrightarrow \mathrm{CO}_{2(a q)}
$$


Throughout the aqueous solution, the homogeneous acid-base reactions are assumed to be in equilibrium ${ }^{38}$, eqs (2)-(4).

$$
\begin{array}{ll}
\mathrm{HCO}_{3}{ }^{-}+\mathrm{OH}^{-} \leftrightarrow \mathrm{CO}_{3}{ }^{2-}+\mathrm{H}_{2} \mathrm{O} & \mathrm{K}_{2} \\
\mathrm{CO}_{2 a q}+\mathrm{H}_{2} \mathrm{O} \leftrightarrow \mathrm{HCO}_{3}{ }^{-}+H^{+} & K_{3} \\
\mathrm{H}^{+}+\mathrm{OH}^{-} \leftrightarrow \mathrm{H}_{2} \mathrm{O} & K_{w}
\end{array}
$$

where $\mathrm{K}_{2}, \mathrm{~K}_{3}$, and $\mathrm{K}_{\mathrm{w}}$ are the equilibrium constants, listed in Table 2 .

\subsection{Electrochemical Reactions}

High purity $\mathrm{CO}_{2}(99.99 \%)$ with $0.01 \% \mathrm{~N}_{2}$ is fed into the cathode gas channel. $\mathrm{CO}_{2}$ will then diffuse through the gas diffusion layer into the cathode catalyst layer where the reduction reactions occur. In this electrochemical cell, potassium bicarbonate is used as an electrolyte. If sufficiently negative cell potential is applied, the $\mathrm{CO}_{2}$ will react with the $\mathrm{H}^{+}$ions, produced by water oxidation at the anode, eq (5), and it will be reduced to $\mathrm{CH}_{3} \mathrm{OH}$ and $\mathrm{C}_{2} \mathrm{H}_{5} \mathrm{OH}$, eqs (6) and (7). Hydrogen evolution reaction (HER), eq (8), may occur and is considered a competing reaction, as it consumes the $\mathrm{H}^{+}$ions necessary for $\mathrm{CO}_{2}$ conversion to $\mathrm{CH}_{3} \mathrm{OH}$ and $\mathrm{C}_{2} \mathrm{H}_{5} \mathrm{OH}$.

Anodic Reaction: 
$10 \mathrm{H}_{2} \mathrm{O} \leftrightarrow 5 \mathrm{O}_{2}+20 \mathrm{H}^{+}+20 e^{-}$

Cathodic Reactions:

$$
\begin{aligned}
& \mathrm{CO}_{2}+6 \mathrm{H}^{+}+6 e^{-} \leftrightarrow \mathrm{CH}_{3} \mathrm{OH}+\mathrm{H}_{2} \mathrm{O} \\
& 2 \mathrm{CO}_{2}+12 \mathrm{H}^{+}+12 e^{-} \leftrightarrow \mathrm{C}_{2} \mathrm{H}_{5} \mathrm{OH}+3 \mathrm{H}_{2} \mathrm{O} \\
& 2 \mathrm{H}^{+}+2 e^{-} \leftrightarrow \mathrm{H}_{2}
\end{aligned}
$$

\subsection{Governing Equations}

The governing equations of the various regions in the electrochemical cell are summarized below.

\subsubsection{Electrolyte Channels}

\subsubsection{Fluid Flow}

The steady, 2D Newtonian laminar flow in the electrolyte channels (catholyte \& anolyte)

is governed by the continuity and Navier-Stokes equations ${ }^{24}$, eqs (9) and (10)

$$
\begin{aligned}
& \nabla .(\rho \boldsymbol{u})=0 \\
& \rho \boldsymbol{u} \cdot \nabla \boldsymbol{u}=\rho g-\nabla p+\cdot\left[\mu(\nabla \boldsymbol{u}+(\nabla \boldsymbol{u}))^{T}-\frac{2}{3} \mu(\nabla \cdot \boldsymbol{u}) \boldsymbol{I}\right]+\boldsymbol{F}_{\boldsymbol{v}}
\end{aligned}
$$


where $\rho$ is the density, $\boldsymbol{u}$ is the velocity vector, $g$ is the gravitational acceleration, $p$ is the pressure, $\mu$ is the dynamic viscosity, $\boldsymbol{I}$ is the identity tensor, and $\boldsymbol{F}_{\boldsymbol{v}}$ is the volume force vector.

\subsubsection{Mass Transport}

Basically, the mass transport for an individual aqueous species $i$ through the electrolyte is governed by equation (11).

$$
\begin{aligned}
& \nabla . N_{i}=R_{i} \\
& i=\mathrm{CO}_{2}, \mathrm{~K}^{+1}, \mathrm{HCO}_{3}{ }^{-1}, \mathrm{CO}_{3}{ }^{-2}, \mathrm{H}^{+1}, \mathrm{OH}^{-1}, \mathrm{CH}_{3} \mathrm{OH}, \mathrm{C}_{2} \mathrm{H}_{5} \mathrm{OH}, \mathrm{O}_{2}
\end{aligned}
$$

$N_{i}$ represents the flux vector of species $i$, and is governed by the Nernst-Plank

$$
\begin{aligned}
& \text { equation }^{48} \text {, eq (12). } \\
& \boldsymbol{N}_{\boldsymbol{i}}=-D_{i} \nabla c_{i}-z_{i} u_{m, i} F c_{i} \nabla \varphi_{l}+\boldsymbol{u} c_{i}
\end{aligned}
$$

where $R_{i}$ is the production or consumption rate expression for species $i, c_{i}$ is the concentration of species $i, F$ is the Faraday constant, $\varphi_{l}$ is the electric potential of the liquid electrolyte, and $D_{i}$ and $z_{i}$ are the diffusion coefficient and charge number of species $i$, respectively, listed in Table 3 .

Table 3. Electrolyte liquid species and their properties 


\begin{tabular}{llll}
\hline Species & $D_{i}\left(\mathrm{~cm}^{2} \mathbf{~ s}^{-1}\right)$ & $z_{i}$ & Ref. \\
\hline $\mathrm{CO}_{2 \text { aq }}$ & $1.92 \times 10^{-5}$ & 0 & 49 \\
$\mathrm{H}^{+}$ & $9.311 \times 10^{-5}$ & +1 & 48,50 \\
$\mathrm{OH}^{-1}$ & $5.273 \times 10^{-5}$ & -1 & 48,50 \\
$\mathrm{~K}^{+1}$ & $1.957 \times 10^{-5}$ & +1 & 48,50 \\
$\mathrm{HCO}_{3}{ }^{-1}$ & $1.185 \times 10^{-5}$ & -1 & 48,50 \\
$\mathrm{CO}_{3}^{-2}$ & $0.923 \times 10^{-5}$ & -2 & 50 \\
$\mathrm{CH}_{3} \mathrm{OH}$ & $0.84 \times 10^{-5}$ & 0 & 49 \\
$\mathrm{C}_{2} \mathrm{H}_{5} \mathrm{OH}$ & $0.84 \times 10^{-5}$ & 0 & 49 \\
$\mathrm{O}_{2}$ & $2.1 \times 10^{-5}$ & 0 & 49 \\
\hline
\end{tabular}

The Nernst-Einstein relation ${ }^{48}$, eq (13), is used for relating the ionic mobility, $u_{m, i}$, of the ionic species to their diffusivity.

$$
u_{m, i}=\frac{D_{i}}{R T}
$$

where, $R$ is the gas constant, and $T$ is the absolute temperature.

Moreover, the current density vector $\boldsymbol{j}$ is proportional to the sum of all species fluxes as expressed by Faraday's law ${ }^{48}$, eq (14).

$$
\boldsymbol{j}=F \sum_{i} Z_{i} \boldsymbol{N}_{i}
$$




\subsubsection{Charge Transport}

The Transport of protons from the anode to the cathode side is assumed to occur by electro-migration only. Furthermore, the charge conservation holds and electron transport can be described by Ohm's law, eqs (15) and (16). ${ }^{48}$

$$
\begin{aligned}
& \nabla . i_{l}=0 \\
& i_{l}=-\sigma_{l} \nabla \varphi_{l}
\end{aligned}
$$

where $\sigma_{l}$ is the average ionic conductivity of the electrolyte, calculated from eq (17). ${ }^{48}$

$$
\sigma_{l}=\left(\frac{F^{2}}{R T}\right)\left(\sum_{i} z_{i}^{2} D_{i} c_{i}\right)
$$

\subsubsection{Cathode Gas Diffusion Layer (GDL)}

\subsubsection{Fluid Flow}

The continuity equation, eq (18), and Brinkman momentum equation ${ }^{24}$ (Brinkman's extension of Darcy's law), eq (19), were used for describing the pressure drop and gas flow within the porous GDL.

$$
\begin{aligned}
& \rho \nabla \cdot(\boldsymbol{u})=0 \\
& { }_{\bar{\varepsilon}}^{\rho} \boldsymbol{u} \cdot \nabla \frac{\boldsymbol{u}}{\varepsilon}=-\nabla p+\nabla \cdot\left[\frac{\mu}{\varepsilon}\left(\nabla \boldsymbol{u}+(\nabla \boldsymbol{u})^{T}\right)-\frac{2}{3}(\nabla \cdot \boldsymbol{u}) \boldsymbol{I}\right]-\left(\frac{\mu}{k}\right) \boldsymbol{u}
\end{aligned}
$$


where, $\rho$ is the gas mixture density, and $\varepsilon$ and $k$ are the porosity and permeability of the porous media, respectively.

\subsubsection{Mass Transport}

The multi-component mass transport in the porous GDL was solved to determine the gas partial pressures at the gas-liquid interface. Maxwell-Stefan equation ${ }^{51}$, eq (20) was used for solving the fluxes of each species in terms of mass fraction.

$$
R_{i}=\nabla .\left\{-\rho \omega_{i} \sum_{i=1}^{n} D_{i j}^{e f f}\left[\frac{M_{g}}{M_{j}}\left(\nabla \omega_{j}+\omega_{j} \frac{\nabla M_{g}}{M_{g}}\right)+\left(x_{j}-\omega_{j}\right) \frac{\nabla P}{P}\right]+\rho u \omega_{i}\right\}
$$

where, $\omega_{i}$ and $x_{j}$ are the mass and mole fraction, respectively, $M_{g}$ is the molar mass of the gas mixture, eq (21), and $\rho$ is the ideal gas mixture density, described by eq (22).

$$
\begin{aligned}
& M_{g}=x_{N_{2}} M_{N_{2}}+x_{C_{2}} M_{C_{2}} \\
& \rho=\left(\sum_{i=1}^{N} X_{i} M_{i} P /(R . T)\right.
\end{aligned}
$$

where, $M_{i}$ is the molecular weight of species $i$. 
The effective diffusivity, $D_{i j}^{e f f}$, in eq (20) is corrected for the porosity, $\varepsilon$, and tortuosity,

$\tau$, of the considered porous medium using the Bruggeman relation, eq (23)

$$
D_{i j}{ }^{e f f}=\frac{\varepsilon}{\tau} D_{i}=\varepsilon^{3 / 2} D_{i j}
$$

where $D_{i j}$ can be estimated from the empirical correlation recommended by Fuller,

Schettler, and Giddings. ${ }^{46}$

$$
D_{i j}=\frac{1.01325 \times 10^{-2} T^{1.75}\left(\frac{1}{M_{i}}+\frac{1}{M_{j}}\right)^{0.5}}{P\left(v_{i}^{1 / 3}+v_{j}^{1 / 3}\right)^{2}}
$$

where $v$ is the diffusion volume, listed in Table 2 .

The mass fraction of $N_{2}$ is then calculated from the overall mass balance, eq (25).

$$
\omega_{N_{2}}=1-\omega_{\mathrm{CO}_{2}}
$$

\subsubsection{Charge Transport}

For the hydrophobic GDL (i.e. there is no electrolyte nor proton transport within the GDL), charge is conserved. The electron transport through the solid phase was described by Ohm's Law, eq (26). 


$$
\nabla \cdot i_{s}=0
$$

where

$$
i_{s}=-\sigma_{s, G D L} \nabla \varphi_{s}
$$

where, $i_{s}$ is the current density of the solid phase of the GDL, $\sigma_{s, G D L}$ and $\varphi_{s}$ are the electronic conductivity and the electric potential of the solid phase of the GDL, respectively.

\subsubsection{Cathode Catalyst Layer (CL)}

As proposed by Lien-Chun Weng et al. ${ }^{21}$, the triple-phase interface is not essential for the high performance of the GDEs. In the present model, it was assumed that $\mathrm{CO}_{2}$ first dissolves into the aqueous solution within the $\mathrm{CL}$, then reacts in its dissolved state. Based on this assumption, the saturation volume fraction of the catalyst layer (i.e., the fraction of liquid electrolyte covering the total pore volume of the porous catalyst layer) needs to be accounted for. Therefore, the $\mathrm{CL}$ active area, $a_{v}$, available for the electroreduction reactions was related to the saturation fraction $S_{C L}$, eq (28). ${ }^{21}$

$$
a_{v}=a_{v}^{0} S_{C L}
$$


The catalyst layer was considered to contain spherical particles with radius $r_{p}$, with an intrinsic porosity $\varepsilon_{C L}^{0}$. The specific surface area $a_{v}^{0}$ of the $C L$ can be calculated from eq $(29) \cdot{ }^{21}$

$$
a_{v}^{0}=\frac{3\left(1-\varepsilon_{C L}^{0}\right)}{r_{p}}
$$

Due to the difficulty in saturation calculation, given the insufficient characteristics data available on the catalyst layer, a constant value of saturation fraction, $S_{C L}$, was taken as shown in Table 2.

The porosity in eq (18) is modified according to eq (30). ${ }^{21}$

$$
\varepsilon_{C L}=\varepsilon_{C L}^{0}\left(1-S_{C L}\right)
$$

\subsubsection{Mass Transport}

Because of the extremely low velocity inside the porous media of the $\mathrm{CL}$, the convection

flux term in Nernst-Plank equation, eq (12), can be neglected. Therefore, the movement of the aqueous species is governed by diffusion and migration only, eq (31).

$$
\boldsymbol{N}_{\boldsymbol{i}}=-D_{i}{ }^{e f f} \nabla c_{i}-z_{i} u_{m, i} F c_{i} \nabla \varphi_{l}
$$

The term $D_{i}^{e f f}$ represents the effective diffusion coefficient of the aqueous species $i$, calculated using the Bruggeman relation, eq (23). 


\subsubsection{Charge Transport}

For the $\mathrm{CL}$, current can be split into two types; ionic current through the electrolyte, and electronic current through the catalyst particles. Similarly, the charge conservation equations can be calculated using Ohm's Law ${ }^{21}$, eqs (32)-(34).

$$
\begin{array}{r}
\nabla . i_{s}=-\nabla . i_{l}=-a_{v} \sum_{k} i_{l o c, \mathrm{k}} \\
i_{l}=-\sigma_{l}^{e f f} \nabla \varphi_{l}
\end{array}
$$

$$
i_{s}=-\sigma_{s}^{e f f} \nabla \varphi_{s}
$$

where $i_{l o c, k}$ is the local current density of electrode reaction with index $k, \sigma_{s}^{e f f}, \sigma_{l}^{e f f}$ are the effective conductivities of the solid and liquid phase, respectively, corrected by the Bruggeman correlation ${ }^{21}$, eqs (35) and (36).

$$
\sigma_{l}^{e f f}=\varepsilon_{l}^{1.5} \sigma_{l} \quad \text { (35) } \quad \sigma_{s}^{e f f}=\varepsilon_{s}^{1.5} \sigma_{s}
$$

\subsubsection{Membrane}

As the work of Yosra et. al. ${ }^{38}$, the membrane was modeled as a homogeneous medium containing fixed ionic charge with a molar concentration $c_{H^{+}, m}$. Charge conservation and Ohm's law are also applicable in the membrane domain;

$$
\begin{aligned}
& \nabla . i_{l, m}=0 \\
& i_{l, m}=-\sigma_{l, m} \nabla \varphi_{l, m}
\end{aligned}
$$


where, $\varphi_{l, m}$ is the membrane potential, and $\sigma_{l, m}$ is the membrane electric conductivity,

listed in Table 2.

At the membrane-electrolyte interfaces, the potential continuity was maintained through considering the Donnan potential shift, $\nabla \varphi_{D} \cdot{ }^{38,53} \mathrm{It}$ arises across the membrane as a result of the differences in $H^{+}$activity in the membrane, $a_{H^{+}, m}$, and the electrolyte, $a_{H^{+}, e}$. These activities can be replaced by their corresponding concentrations $c_{H^{+}, m}$ and $c_{H^{+}, e}$, due to the low concentration of ions, eq (39). ${ }^{53}$

$$
\nabla \varphi_{D}=\varphi_{l, m}-\varphi_{l, e}=\frac{R T}{F} \ln \left(\frac{c_{H^{+}, m}}{c_{H^{+}, e}}\right)
$$

\subsubsection{Electrochemical Kinetics}

The electrochemical kinetic reactions at both cathode and anode can be described by the modified Butler-Volmer equation, eq (40), also known as concentration-dependent Butler-Volmer equation.

$$
i_{l o c, k}=i_{0, \mathrm{k}}\left[\frac{C_{R, S}}{C_{R, B}} \exp \left(\frac{\alpha_{a} z F}{R T} \eta\right)-\frac{C_{O, S}}{C_{O, B}} \exp \left(\frac{\alpha_{c} z F}{R T} \eta\right)\right]
$$

Here, $i_{0, \mathrm{k}}$ is the equilibrium exchange current density of reaction $k, c_{R, S}$ and $C_{R, B}$ are the surface and bulk concentrations of the reduced species, respectively, and $C_{O, S}$ and $C_{O, B}$ are the surface and bulk concentrations of the oxidized species, respectively. $\alpha_{a}$ and $\alpha_{c}$ 
represent the anodic and cathodic charge transfer coefficients, respectively, listed in Table 4. The term $z$ represents the number of electrons transferred in the rate limitingstep, and $\eta$ represents the activation overpotential.

\section{Table 4. Electrode Kinetics Parameters}

\begin{tabular}{llll}
\hline Parameter & \multicolumn{1}{l}{ Symbol } & Value & Unit \\
\hline \multicolumn{2}{l}{ Charge transfer coefficients } & \multicolumn{2}{l}{} \\
Anode & $\alpha_{a}$ & 0.5 & - \\
Cathode & $\alpha_{c}$ & 0.5 & - \\
Reference Conc. & $c_{r e f}$ & 1 & $\mathrm{~mol} \mathrm{I}^{-1}$ \\
Exchange Current Densities at Anode & & \\
OER & $i_{0, O E R}$ & 9.4223 & $\mathrm{~A} \mathrm{~m}^{-2}$ \\
\hline
\end{tabular}

Similar to the work of Yosra et. al. ${ }^{38}$, equation (40) can be reduced to the following equations:

Anode side

$$
i_{l o c, O E R}=i_{0, O E R} \exp \left(\frac{\left(\alpha_{a}+\alpha_{c}\right) F \eta}{R T}\right)
$$




\section{Cathode side}

$$
\begin{aligned}
& i_{l o c, \mathrm{CH}_{3} \mathrm{OH}}=-i_{0, \mathrm{CH} \mathrm{H}_{3} \mathrm{OH}}\left(\frac{c_{c 0_{2}} c_{\mathrm{H}}+}{c_{r e f}^{2}}\right) \exp \left(\frac{-\alpha_{c} F \eta}{R T}\right) \\
& i_{l o c, \mathrm{C}_{2} \mathrm{H}_{5} \mathrm{OH}}=-i_{0, \mathrm{C}_{2} \mathrm{H}_{5} \mathrm{OH}}\left(\frac{c_{c_{\mathrm{CO}_{2}} \mathrm{H}_{H^{+}}}}{c^{2}{ }_{r e f}}\right) \exp \left(\frac{-\alpha_{c} F \eta}{R T}\right) \\
& i_{l o c, \mathrm{HER}}=i_{0, \mathrm{HER}}\left(\frac{\left(\alpha_{a}+\alpha_{c}\right) F}{R F}\right) \eta
\end{aligned}
$$

Overpotential

$$
\eta_{k}=\phi_{s}-\phi_{l}-E_{e q, k}
$$

where, $c_{r e f}$ is the reference concentration, and $E_{e q, k}$ is the equilibrium potential (Nernst

potential) of reaction $k$.

The exchange current densities in the above equations are obtained by fitting these forms of Butler-Volmer equation to the current densities from the experimental results. The model has related the exchange current density of the liquid products to the process conditions through developing an empirical relation, eq (46).

$$
i_{0, \mathrm{k}}=i_{0, \mathrm{k}}^{*}\left(\frac{j_{a p p}}{j^{*}}\right)^{a}\left(\frac{Q_{g} / A}{Q_{g}{ }^{*}}\right)^{b}\left(\frac{Q_{e} / A}{Q_{e}{ }^{*}}\right)^{c}
$$

where $i_{0, \mathrm{k}}^{*}, a, b$, and $c$ are the kinetics fitting constants. 
The values of $\mathrm{j}^{*}, Q_{g}{ }^{*}$, and $Q_{e}{ }^{*}$ are based on the optimum values from the experimental

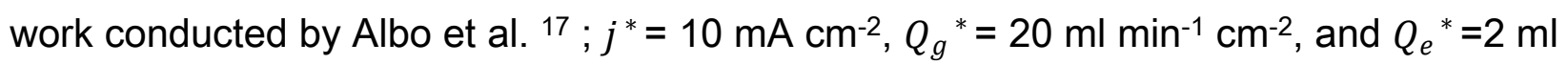
$\min ^{-1} \mathrm{~cm}^{-2}$.

The equilibrium potential $E_{\text {eq, }}$ in eq (45) can be described by Nernst equation, eq (47). ${ }^{54}$

$$
E_{\text {eq, },}=E^{0}+\frac{R T}{n F} \ln \left[\frac{a_{\text {products }}}{a_{\text {reactants }}}\right]
$$

where, $E^{0}$ is the standard potential for the considered half-cell reaction, as shown in Table 5. The term a represents the activity that can be replaced by the concentration, eqs (48) and (49).

Table 5. Standard potentials for the considered electrochemical reactions

\begin{tabular}{llll}
\hline Half-cell reaction & $\mathbf{E}^{\mathbf{0}}$ & \\
\cline { 1 - 1 } & eq (5) & 1.23 \\
$\mathrm{CH}_{3} \mathrm{OH}$ & eq (6) & 0.02 \\
$\mathrm{C}_{2} \mathrm{H}_{5} \mathrm{OH}$ & eq (7) & 0.08 \\
$\mathrm{HER}$ & eq (8) & 0 & {$\left[\mathrm{E}^{0} \text { vs. } \mathrm{Ag} / \mathrm{AgCL}=\mathrm{E}^{0} \text { vs. RHE }-0.059 \mathrm{PH}-0.197\right]^{55}$}
\end{tabular}

$\mathrm{E}^{0}$ values are reported under standard conditions [1 atm and 250C] vs. reversible hydrogen electrode (RHE) in aqueous media. ${ }^{56}$

$$
E_{\text {eq, } \mathrm{CH}_{3} \mathrm{OH}}=E_{\mathrm{CH}_{3} \mathrm{OH}}^{0}+\frac{R T}{6 F} \ln \left[\frac{C_{\mathrm{CH}_{3} \mathrm{OH}}}{C_{\mathrm{CO}_{2} \mathrm{C}^{+}}^{6}}\right] \quad \text { vs. } \mathrm{Ag} / \mathrm{AgCL}
$$




$$
E_{e q, C_{2} \mathrm{H}_{5} \mathrm{OH}}=E_{C_{2} \mathrm{H}_{5} \mathrm{OH}}^{0}+\frac{R T}{12 \mathrm{~F}} \ln \left[\frac{C_{C_{2} \mathrm{H}_{5} \mathrm{OH}}^{2}}{C_{\mathrm{CO}_{2} C_{H}}^{12}}\right] \text { vs. Ag/AgCL }
$$

Therefore, the reaction source term $R_{i}$ in eq (11), can be calculated from the following relations:

Anodic Reaction Source term:

$$
R_{O_{2}}=\frac{v i_{l o c, ~ O E R}}{20 F}
$$

Cathodic Reaction Source terms:

$$
\begin{aligned}
& R_{\mathrm{CH}_{3} \mathrm{OH}}=\frac{a_{v} i_{l o c, \mathrm{CH}_{3} \mathrm{OH}}}{6 \mathrm{~F}} \\
& R_{\mathrm{C}_{2} \mathrm{H}_{5} \mathrm{OH}}=\frac{a_{v} i_{0, C_{2} \mathrm{H}_{5} \mathrm{OH}}}{12 \mathrm{~F}} \\
& R_{\mathrm{H}_{2}}=\frac{a_{v} i_{l o c, \mathrm{HER}}}{2 \mathrm{~F}}
\end{aligned}
$$

where $v$ is the stoichiometric coefficient of $\mathrm{O}_{2}$ in eq (5).

\subsubsection{Rate of $\mathrm{CO} 2$ absorption-Film theory:}

When the gaseous $\mathrm{CO}_{2}$ comes into contact with the liquid electrolyte, at the GDL-CL interface, it is absorbed into the electrolyte through a thin film. The steady-state flux across this thin film can be described in terms of the gas-to-liquid mass transfer coefficient $K_{G L, \mathrm{CO}_{2}}$, eqs (54) and (55). ${ }^{49}$ 


$$
\begin{aligned}
& N_{\mathrm{CO}_{2}, \mathrm{abs}}=K_{G L, \mathrm{CO}_{2}}\left(c_{\mathrm{CO}_{2}}^{*}-c_{\mathrm{CO}_{2}}\right) \\
& K_{G L, \mathrm{CO}_{2}}=\frac{D_{\mathrm{CO}_{2}}}{\delta_{T f}}
\end{aligned}
$$

where $\boldsymbol{N}_{\mathbf{C O}_{2, \text { abs }}}$ is $\mathrm{CO}_{2}$ absorption flux relative to the interface, $\mathrm{C}_{\mathrm{CO}_{2}}^{*}$ and $\mathrm{C}_{\mathrm{CO}_{2}}$ are the interfacial and bulk concentrations in the electrolyte, and $\delta_{T f}$ is the thin-film thickness, shown in Table 2.

$\mathrm{C}_{\mathrm{CO}}^{*}$ represents the solubility limit of $\mathrm{CO}_{2}$ in the electrolyte and is proportional to the partial pressure of $\mathrm{CO}_{2}$ as stated by Henry's Law, eq (56).

$$
c_{\mathrm{CO}_{2}}^{*}=\mathrm{H}_{\mathrm{CO}_{2}} \cdot p_{g} \cdot Y_{\mathrm{CO}_{2}}
$$

Therefore,

$$
\boldsymbol{N}_{\mathrm{Co}_{2}, \boldsymbol{a b s}}=K_{\mathrm{GL} \mathrm{CO}_{2}}\left(\mathrm{H}_{\mathrm{CO}_{2}} \cdot p_{g} \cdot Y_{\mathrm{CO}_{2}}-\beta \cdot \mathrm{c}_{\mathrm{CO}_{2}}\right)
$$

where $\beta$ is also a fitting parameter, used to differentiate the concentration of $\mathrm{CO}_{2}$ in the depletion boundary layer ${ }^{57}$, at CL-GDL interface, from that of bulk electrolyte concentration.

\subsection{Boundary Conditions}


The internal boundary conditions are given based on the continuity and mass flux balance to satisfy the general mass and species conservation of the entire cell. The boundary conditions at each interface are presented in details in Table 6.

Table 6. Boundary Conditions

\begin{tabular}{|c|c|c|}
\hline Position & Condition & \\
\hline $\begin{array}{l}\text { CGC-GDL } \\
\text { Interface }\end{array}$ & $\begin{array}{l}\text { Constant inlet gas velocity } \\
\text { Constant inlet gas composition } \\
\text { External applied current density }\end{array}$ & $\begin{array}{l}\boldsymbol{u}=-U_{g}^{0} \\
Y_{C O_{2}}=Y_{C O_{2}, i n} \\
j=j_{a p p}\end{array}$ \\
\hline Electrolyte Inlets & $\begin{array}{l}\text { Constant inlet electrolyte } \\
\text { velocity } \\
\text { Constant inlet species } \\
\text { concentrations } \\
\text { Charge insulation }\end{array}$ & $\begin{array}{l}\boldsymbol{u}=-U_{l}^{0} \boldsymbol{n} \\
-\boldsymbol{n} \cdot \boldsymbol{N}_{\boldsymbol{i}}=\boldsymbol{n} \cdot\left(\boldsymbol{u} c_{i, i n}\right) \\
-\boldsymbol{n} \cdot \boldsymbol{i}_{\boldsymbol{l}}=0, \quad-\boldsymbol{n} \cdot \boldsymbol{i}_{\boldsymbol{s}}=0\end{array}$ \\
\hline $\begin{array}{l}\text { Electrolyte } \\
\text { Outlets }\end{array}$ & $\begin{array}{l}\text { Constant pressure } \\
\text { (atmospheric) } \\
\text { Zero-diffusive flux of species } \\
\text { Charge insulation }\end{array}$ & $\begin{array}{l}P=P_{a t m} \\
-\boldsymbol{n} \cdot D_{i} \nabla c_{i}=0 \\
-\boldsymbol{n} \cdot \boldsymbol{i}_{\boldsymbol{l}}=0, \quad-\boldsymbol{n} \cdot \boldsymbol{i}_{\boldsymbol{s}}=0\end{array}$ \\
\hline GDL-CL Interface & $\begin{array}{l}\text { Species flux continuity }\left(\mathrm{CO}_{2} \text { is }\right. \\
\text { absorbed into the electrolyte }) \\
\text { Current conservation }\end{array}$ & $\begin{array}{l}-n \cdot N_{C O_{2}}=N_{C O_{2}, a b s .} \\
n \cdot i_{s . G D L}=n \cdot i_{s . C L}\end{array}$ \\
\hline
\end{tabular}




\begin{tabular}{|c|c|c|}
\hline Position & Condition & \\
\hline \multirow[b]{2}{*}{$\begin{array}{l}\text { CL-Catholyte } \\
\text { Interface }\end{array}$} & & $\boldsymbol{i}_{\boldsymbol{l}}=0$ \\
\hline & $\begin{array}{l}\text { Species flux continuity } \\
\text { Ionic current conservation }\end{array}$ & $\begin{array}{l}-\boldsymbol{n} . \boldsymbol{N}_{\boldsymbol{i}}=\sum_{m} R_{i, m}, R_{i}=\frac{v i_{l o c}}{z_{i} F}, \\
\boldsymbol{n} . \boldsymbol{i}_{\boldsymbol{l} . C L}=\boldsymbol{n} . \boldsymbol{i}_{\text {l.e }}\end{array}$ \\
\hline $\begin{array}{l}\text { Catholyte- } \\
\text { Membrane } \\
\text { Interface }\end{array}$ & $\begin{array}{l}\text { Proton flux continuity } \\
\text { Current conservation } \\
\text { Donnan potential }\end{array}$ & $\begin{array}{l}\boldsymbol{n} . \boldsymbol{N}_{\boldsymbol{H}^{+} . \boldsymbol{e}}=\boldsymbol{n} \cdot \frac{\boldsymbol{i}_{\boldsymbol{l} \cdot \boldsymbol{m}}}{F} \\
\boldsymbol{n} \cdot \boldsymbol{i}_{\boldsymbol{l} \boldsymbol{e}}=\boldsymbol{n} \cdot \boldsymbol{i}_{\boldsymbol{l} \cdot \boldsymbol{m}} \\
\varphi_{l, m}=\varphi_{l, e}+\frac{R T}{F} \ln \left(\frac{c_{H^{+}, m}}{c_{H^{+}, e}}\right)\end{array}$ \\
\hline $\begin{array}{l}\text { Anolyte- } \\
\text { Membrane } \\
\text { Interface }\end{array}$ & $\begin{array}{l}\text { Current conservation } \\
\text { Donnan Potential }\end{array}$ & $\begin{array}{l}\boldsymbol{n . N}_{\boldsymbol{H}^{+} . \boldsymbol{e}}=n \cdot \frac{\boldsymbol{i}_{\boldsymbol{l} \cdot \boldsymbol{m}}}{F} \\
\boldsymbol{n} \cdot \boldsymbol{i}_{\boldsymbol{l} \cdot \boldsymbol{e}}=\boldsymbol{n} \cdot \boldsymbol{i}_{\boldsymbol{l} \cdot \boldsymbol{m}} \\
\varphi_{l, m}=\varphi_{l, e}+\frac{R T}{F} \ln \left(\frac{c_{H^{+}, m}}{c_{H^{+}, e}}\right)\end{array}$ \\
\hline Anode Surface & $\begin{array}{l}\text { Species flux continuity } \\
\text { External applied potential } \\
\text { Current conservation }\end{array}$ & $\begin{array}{l}-\boldsymbol{n} \cdot \boldsymbol{N}_{\boldsymbol{i}}=\sum_{m} R_{i, m} \quad, \boldsymbol{R}_{\boldsymbol{i}}=\frac{v i_{\boldsymbol{l o c}}}{z_{i} F} \\
\boldsymbol{\varphi}_{\boldsymbol{s}, \boldsymbol{e x t}}=\boldsymbol{\varphi}_{\boldsymbol{a}} \\
\boldsymbol{n} . \boldsymbol{i}_{\boldsymbol{l}}=i_{\text {total }}=\sum_{m} i_{l o c, m}\end{array}$ \\
\hline Walls & $\begin{array}{l}\text { No-slip boundary condition } \\
\text { No Flux } \\
\text { Charge insulation }\end{array}$ & $\begin{array}{l}u=0 \\
-n \cdot N_{i}=0 \\
-n \cdot i_{l}=0 \quad, \quad-n \cdot i_{s}=0\end{array}$ \\
\hline
\end{tabular}


The concentrations of the different species entering the electrolyte $c_{i, i n}$ were previously calculated in the work of Yosra, et. al. ${ }^{38}$ from the equilibrium constraints along with the carbon balance and electroneutrality condition.

\subsection{Cell Performance - Faradaic Efficiency (FE)}

Faradaic efficiency (FE), the selectivity of a reaction towards a particular product, is a good indication of cell performance. While HER is the side reaction, the faradaic efficiency for other products can be calculated as follows:

$$
\begin{aligned}
& F E_{\mathrm{CH}_{3} \mathrm{OH}}(\%)=\frac{i_{\mathrm{CH}_{3} \mathrm{OH}}}{i_{\text {total }}} \times 100 \\
& F E_{\mathrm{C}_{2} \mathrm{H}_{5} \mathrm{OH}}(\%)=\frac{i_{C_{2} \mathrm{H}_{5} \mathrm{OH}}}{i_{\text {total }}} \times 100
\end{aligned}
$$

where the average total current density, $i_{\text {total }}$, equals the sum of the average current densities for all of the cathodic reactions:

$$
i_{\text {total }}=\sum_{m} i_{l o c, m}=i_{\mathrm{CH}_{3} \mathrm{OH}}+i_{C_{2} \mathrm{H}_{5} \mathrm{OH}}+i_{\mathrm{HER}}
$$

\subsection{Numerical method}

The previous governing equations together with the boundary and inlet conditions were solved simultaneously using a commercially available software package, COMSOL 
Multiphysics ${ }^{\circledR}$ v5.2. A user-defined mesh with mapped distribution was used in each domain (i.e., the GDL, CL, catholyte, membrane, and anolyte domains). The number of elements for each domain was varied according to the accuracy required in the solution. The final mesh, contained 375 quad elements, 140 edge elements and 12 vertex elements with a minimum and average element equal to unity. The model was solved with the base case parameters, using the built-in direct solver PARDISO (Parallel Sparse Direct Solver), with a relative tolerance of 0.001 , and a total of 9324 of degrees of freedom through a fully coupled approach.

For this non-linear system to be converged, the stationary solver was divided into five sequenced steps. In the "Free and Porous Media Flow" interface was solved first since the solution of its equations is not affected by other interfaces in the model. Then, its solution is stored to describe the velocity field for the Maxwell-Stefan and Nernst-Plank equations. Secondly, the "Transport of Concentrated Species" interface together with the flow coupling was solved. Afterwards, the two "Secondary Current Distribution" interfaces were solved for both the electrolyte and membrane to estimate their electric fields. Consequently, their solution was stored to describe the migration-diffusion equation. The 
pre-mentioned solution was used as an initial value for the dependent variables in the "Transport of Diluted Species" interface to get the concentration distribution. Finally, all the interfaces were solved simultaneously to get the final results. Finally, parametric sweeps were used for investigating the effect of changing cell operating conditions on its performance.

\section{Results \& Discussion}

\subsection{Experimental Results}

The use of $\mathrm{Cu}_{2} \mathrm{O}$-based GDEs for the electrochemical reduction of $\mathrm{CO}_{2}$ led primarily to the formation of $\mathrm{CH}_{3} \mathrm{OH}$, together with small quantities of $\mathrm{C}_{2} \mathrm{H}_{5} \mathrm{OH}$. The results presented by Albo et. al., $2016{ }^{33}$ were used for validation. Besides, additional experimental tests were carried out to validate the model. $\mathrm{CH}_{3} \mathrm{OH}$ production rate and Faradaic efficiency (FE) were calculated at different applied current densities and gas flow rates, and results are presented in Tables 7 and 8. 
Table 7. Rate and FE of $\mathrm{CH}_{3} \mathrm{OH}$ and $\mathrm{C}_{2} \mathrm{H}_{5} \mathrm{OH}$ using $\mathrm{Cu}_{2} \mathrm{O}-\mathrm{ZnO}$ GDEs as a function of $\mathrm{j}$,

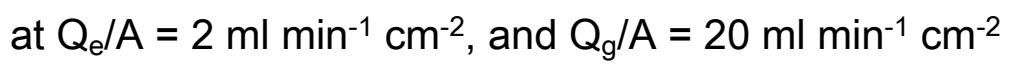

\begin{tabular}{cccccc}
\hline$E$ & $j$ & \multicolumn{2}{c}{ Rate $\left(\mu \mathrm{mol} \mathrm{m}^{-2} \mathrm{~s}^{-1}\right)$} & \multicolumn{2}{c}{$\mathrm{FE} \mathrm{( \% )}$} \\
\cline { 3 - 6 }$(\mathrm{V})$ & $\left.(\mathrm{mA} \mathrm{cm})^{-2}\right)$ & $\mathrm{CH}_{3} \mathrm{OH}$ & $\mathrm{C}_{2} \mathrm{H}_{5} \mathrm{OH}$ & $\mathrm{CH}_{3} \mathrm{OH}$ & $\mathrm{C}_{2} \mathrm{H}_{5} \mathrm{OH}$ \\
\hline-0.89 & 6 & 21.0 & 2.15 & 24.3 & 4.9 \\
-1.02 & 8 & 37.6 & 2.64 & 43.5 & 6.1 \\
-1.19 & 9 & 48.4 & 3.58 & 56 & 8.3 \\
\hline
\end{tabular}

Table 8. Rate and FE for $\mathrm{CO}_{2}$ electrochemical reduction to $\mathrm{CH}_{3} \mathrm{OH}$ at different gas flow rates $\left(Q_{g} / A\right)$ with $\mathrm{Cu}_{2} \mathrm{O} / \mathrm{ZnO}$ GDEs, at $\mathrm{j}=10 \mathrm{~mA} \mathrm{~cm}{ }^{-2}, Q_{\mathrm{e}} / \mathrm{A}=2 \mathrm{ml} \mathrm{min}^{-1} \mathrm{~cm}^{-2}$

\begin{tabular}{llll}
\hline $\mathrm{E}(\mathrm{V})$ & $\mathrm{Q}_{\mathrm{g}} / \mathrm{A}\left(\mathrm{ml} \mathrm{min}^{-1} \mathrm{~cm}^{-2}\right)$ & Rate $\left(\mu \mathrm{mol} \mathrm{m}^{-2} \mathrm{~s}^{-1}\right)$ & $\mathrm{FE}(\%)$ \\
\hline-1.77 & 12.5 & 28.5 & 16.5 \\
-1.58 & 15 & 41.3 & 23.9 \\
-1.38 & 17.5 & 51.1 & 29.6 \\
\hline
\end{tabular}

\subsection{Parametric Estimation and Model Validation}


Values from the literature ${ }^{38}$ were used as a starting point for the first round of calculation of the kinetics fitting parameters, then a trial and error method was applied together with COMSOL parametric sweeps. Percentage error ${ }^{24}$ was calculated according to eq (61),

$$
\text { error }_{i} .(\%)=\frac{r_{l}^{\text {num. }}-r_{l}^{\text {exp. }}}{r_{l}^{\text {exp. }}} \times 100 \%
$$

Here, the subscript $i$ presents a single point at which the production rate was calculated.

The kinetic fitting constants in eq (46) were obtained by minimizing the percentage error between the resulting production rate of model and experiment while varying the applied current density. The fitting constants are listed in Table 9.

Table 9. Fitting parameters in the electrochemical reduction kinetic equations

\begin{tabular}{llll}
\hline Parameter & Symbol & Value & Unit \\
\hline Exchange Current Densities at Cathode & & \\
Methanol & $i_{0, \mathrm{CH}_{3} \mathrm{OH}}^{*}$ & $1.335 \times 10^{10}$ & A.m-2 \\
Ethanol & $i_{0, \mathrm{C}_{2} \mathrm{H}_{5} \mathrm{OH}}^{*}$ & $3.070 \times 10^{10}$ & A.m-2 \\
& $a$ & 2 & - \\
& $b$ & 1 & - \\
& $c$ & 0.5 & - \\
HER & $i_{0, H E R}$ & $10^{3}$ & A.m ${ }^{-2}$
\end{tabular}




\begin{tabular}{llll}
\hline Parameter & Symbol & Value & Unit \\
\hline Conc. fraction & $\beta$ & 0.004 & - \\
\hline
\end{tabular}

\subsection{Effect of Applied Current Density}

Model validation was performed by comparing the effect of varying the applied current density, j, from 5 to $10 \mathrm{~mA} \mathrm{~cm}^{-2}$, on the production rate and the faradaic efficiency, $\mathrm{FE}$, of $\mathrm{CH}_{3} \mathrm{OH}$ and $\mathrm{C}_{2} \mathrm{H}_{5} \mathrm{OH}$, as shown in Fig. 3. Flow rates of both the electrolyte and the $\mathrm{CO}_{2}$

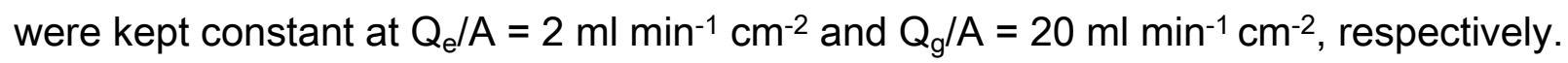

According to Fig. 3.a, the production rate of $\mathrm{CH}_{3} \mathrm{OH}$ and $\mathrm{C}_{2} \mathrm{H}_{5} \mathrm{OH}$ depends on the amount of applied current density; as the current density increases, the production rate of both $\mathrm{CH}_{3} \mathrm{OH}$ and $\mathrm{C}_{2} \mathrm{H}_{5} \mathrm{OH}$ increases up to a current density of $9 \mathrm{~mA} \mathrm{~cm}-2$. After this value, a shift between the measured experimental and modeling results was observed. The same trend was obtained when comparing modeling results of faradaic efficiency, FE, with experimental ones, as shown in Fig. 3.b. An interesting fit between modeling and experimental results was maintained, after which a shift in the results was observed after an applied current density of nearly $9 \mathrm{~mA} \mathrm{~cm}^{-2}$. 

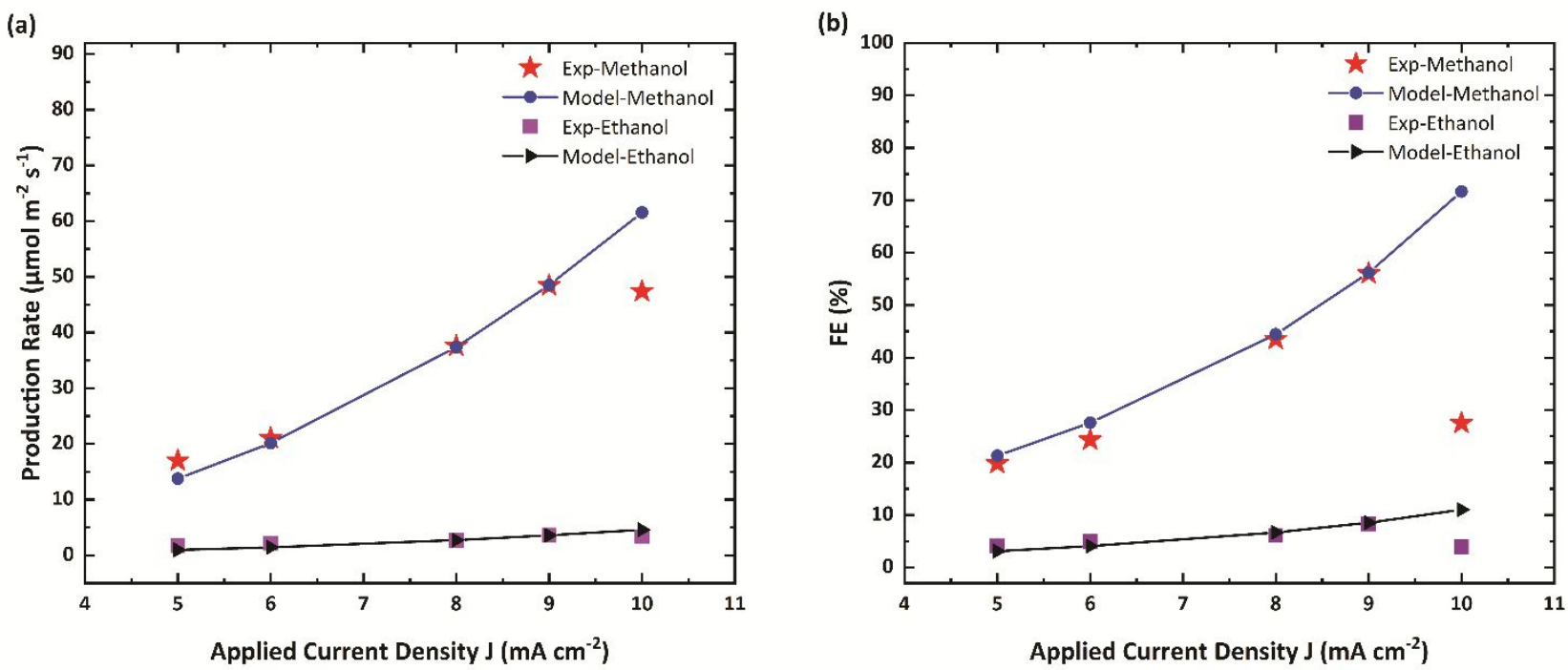

Fig. 3. Effect of applied current density on (a) Production rate of $\mathrm{CH}_{3} \mathrm{OH}$ and $\mathrm{C}_{2} \mathrm{H}_{5} \mathrm{OH}$, and (b) $\mathrm{FE}$ of $\mathrm{CH}_{3} \mathrm{OH}$ and $\mathrm{C}_{2} \mathrm{H}_{5} \mathrm{OH}$, at constant $\mathrm{Q}_{\mathrm{e}} / \mathrm{A}=2 \mathrm{ml} \mathrm{min}^{-1} \mathrm{~cm}^{-2}$, and $\mathrm{Q}_{\mathrm{g}} / \mathrm{A}=20 \mathrm{ml}$ $\mathrm{min}^{-1} \mathrm{~cm}^{-2}$

This may be attributed to the accumulation of the products near the electrode which limits the available $\mathrm{CO}_{2}$ for further reaction, as outlined by Weng et al. ${ }^{21}$ and Albo et al. ${ }^{17,37}$ Hence, a drop in the production rate and faradaic efficiency, FE, of both $\mathrm{CH}_{3} \mathrm{OH}$ and $\mathrm{C}_{2} \mathrm{H}_{5} \mathrm{OH}$ was observed, as shown in Fig. 3. When using GDE, mass transfer limitation is greatly reduced and will occur at a relatively high current density compared to that of a planner electrode, according to Weng et al. ${ }^{21}$ and Castillo et al. ${ }^{58}$ Experimental results in Fig. 3, show that a limiting current density, $i_{l}$, was approached at nearly $9 \mathrm{~mA} \mathrm{~cm}^{-2}$ that 
caps the $\mathrm{CH}_{3} \mathrm{OH}$ production rate to nearly $50 \mu \mathrm{mol} \mathrm{m} \mathrm{m}^{-2} \mathrm{~s}^{-1}$. In the present model, the limiting current density was not accounted for, as the Nernst diffusion layer thickness is unknown, hence, the difference between the experimental and the modeling data occurred after the $9 \mathrm{~mA} \mathrm{~cm}{ }^{-2}$ current density. This may be considered for future development of the current work.

Moreover, the increase in the applied current density reflects an increase in system energy. However, this energy is consumed by side reactions ${ }^{17,21,37}$, such as the HER due to water hydrolysis, or $\mathrm{CO}$ production instead of $\mathrm{CH}_{3} \mathrm{OH}$ production, which was not accounted for in the model. This may interpret the shift in selectivity data that was measured experimentally after the $9 \mathrm{~mA} \mathrm{~cm}^{-2}$ applied current density, Fig. 3.

According to the literature ${ }^{17}$, $\mathrm{Cu}$-based GDEs are more selective to $\mathrm{CH}_{3} \mathrm{OH}$ formation over $\mathrm{C}_{2} \mathrm{H}_{5} \mathrm{OH}$. This was confirmed experimentally and captured by the model, as shown in Fig. 3. When using $\mathrm{Cu}_{2} \mathrm{O}-\mathrm{ZnO}$ GDE, nearly $56 \% \mathrm{FE}$ of $\mathrm{CH}_{3} \mathrm{OH}$ was obtained compared to $8 \%$ maximum $\mathrm{FE}$ for $\mathrm{C}_{2} \mathrm{H}_{5} \mathrm{OH}$.

In general, results obtained from the model and the experimental setup are consistent. The root mean squared error (RMSE) between the experimental and simulated average 
production rates were calculated according to eq (62). The RMSE together with the percentage error, eq $(61)^{24}$, gives an indication of the accuracy of the model.

$$
R M S E=\sqrt{\frac{1}{N} \sum_{k=1}^{N}\left(r_{\text {total }}^{\text {num }}-r_{\text {total }}^{\exp }\right)^{2}}
$$

A root mean squared error (RMSE) of $1.69 \mu \mathrm{mol} \mathrm{m}^{-2} \mathrm{~s}^{-1}$ and an average percentage error of $6 \%$ were obtained. This reflects a good agreement between the model and the experimental results.

\subsection{Effect of Gas Flow Rate}

The relation between the production rate and selectivity, $\mathrm{FE}$, of $\mathrm{CH}_{3} \mathrm{OH}$ and gas flow rate, $Q_{g}$, was investigated, as shown in Fig. 4. The applied current density and the

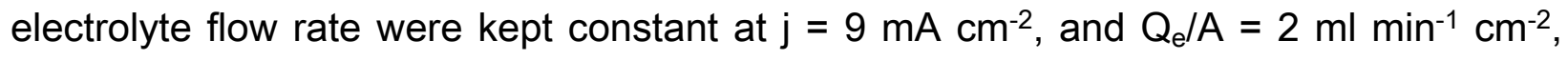
respectively. It was found that the production rate and $\mathrm{FE}$ of $\mathrm{CH}_{3} \mathrm{OH}$ increase as the flow rate of feed $\mathrm{CO}_{2}$ increases. This was compared with the results obtained through experimental testing and there was a good consistency until a gas flow rate value of 17.5 $\mathrm{ml} \mathrm{min}{ }^{-1} \mathrm{~cm}^{-2}$, after which the production rate and selectivity, FE, no longer increase with the increase in the gas flow rate, opposite to the modeled trend at that point. 

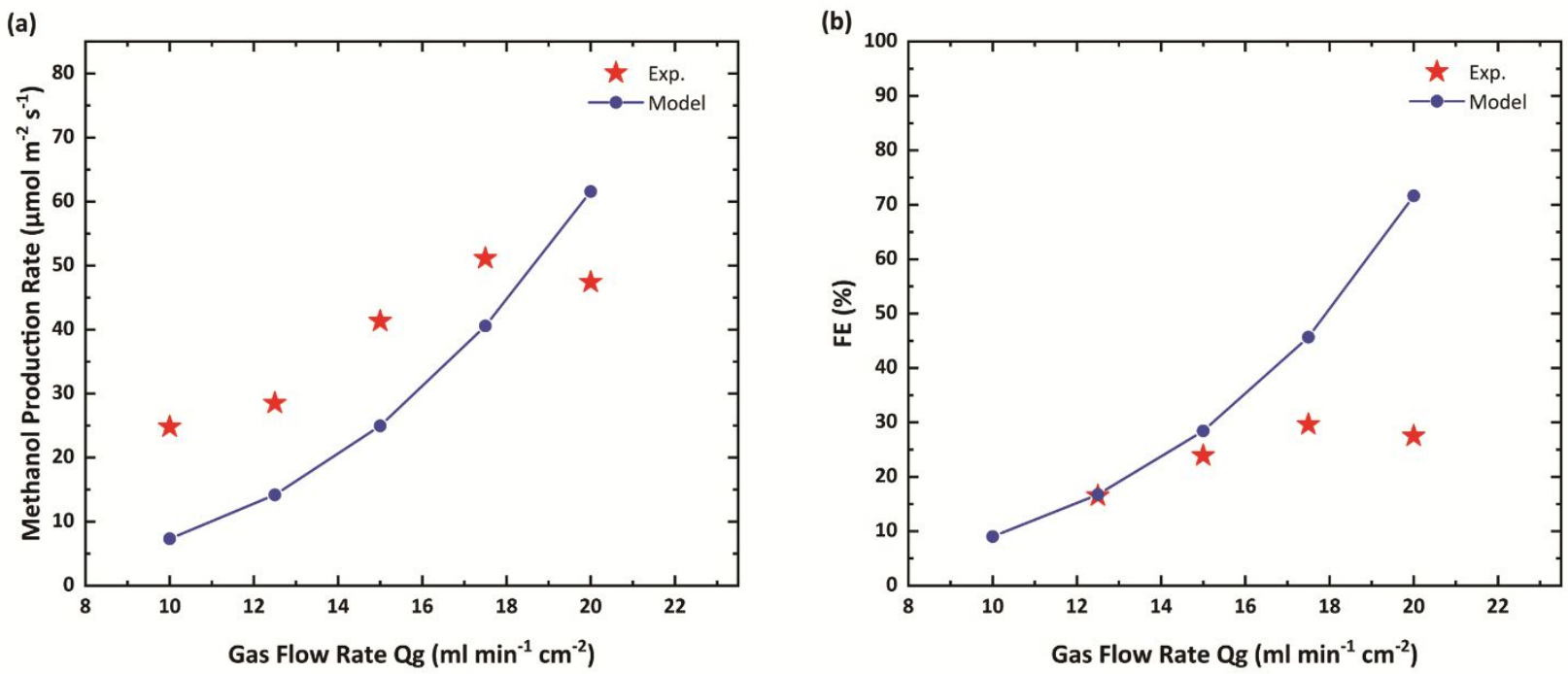

Fig. 4. Effect of Gas flow rate on (a) $\mathrm{CH}_{3} \mathrm{OH}$ production rate, and (b) $\mathrm{FE}$ of $\mathrm{CH}_{3} \mathrm{OH}$, at

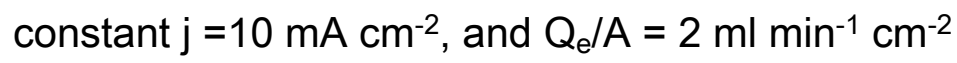

Assuming constant CL saturation in the model could have caused such deviation between the modeling and experimental results. As the gas flow rate increases, it is believed that the $\mathrm{CL}$ saturation, $S_{C L}$, percentage will decrease. Increasing the $\mathrm{CO}_{2}$ flow rate will cause the electrolyte layer to become thinner, which will reduce the mass transfer barrier as outlined by Weng et al. ${ }^{21}$ Hence the production rate of the $\mathrm{CH}_{3} \mathrm{OH}$ increases with the increase in the $\mathrm{CO}_{2}$ gas flow rate. However, further increase in the gas flow rate to higher levels will interfere with the spreading of the electrolyte layer and the three- 
phase interface through the CL may disappear (i.e., $S_{C L}=$ zero) in some places, so, the production rate will drop. ${ }^{21}$

In another case scenario, Albo et al. ${ }^{17,37}$ attributed such reduction in the production rate and $\mathrm{FE}$ of $\mathrm{CH}_{3} \mathrm{OH}$ to the deterioration caused by the detachment of the catalyst metal particles after continuous operation at high flow rate. This will alter the catalyst stability causing reduction at such high flow rate. High gas flow rates would cause excessive gas penetration into the catholyte channel, disturbing the flow, and lowering the stability of the cell. ${ }^{59}$ This can be considered to identify the optimum working inlet gas flow rate during the design of GDE based electrochemical cell.

\subsection{Effect of Electrolyte Flow Rate}

The effect of increasing the electrolyte flow rate by several orders of magnitude on the $\mathrm{CH}_{3} \mathrm{OH}$ production rate was investigated, as shown in Fig. 5. The model was able to capture the trend confirmed through the experimental testing by developing an empirical eq (46). At low electrolyte flow rates, the production rate of $\mathrm{CH}_{3} \mathrm{OH}$ was nearly constant, 
as confirmed in the literature. ${ }^{17,18,32,58}$ However, when the electrolyte flow rate increased, the production rate increased rapidly in agreement with Weng et al. ${ }^{18}$.

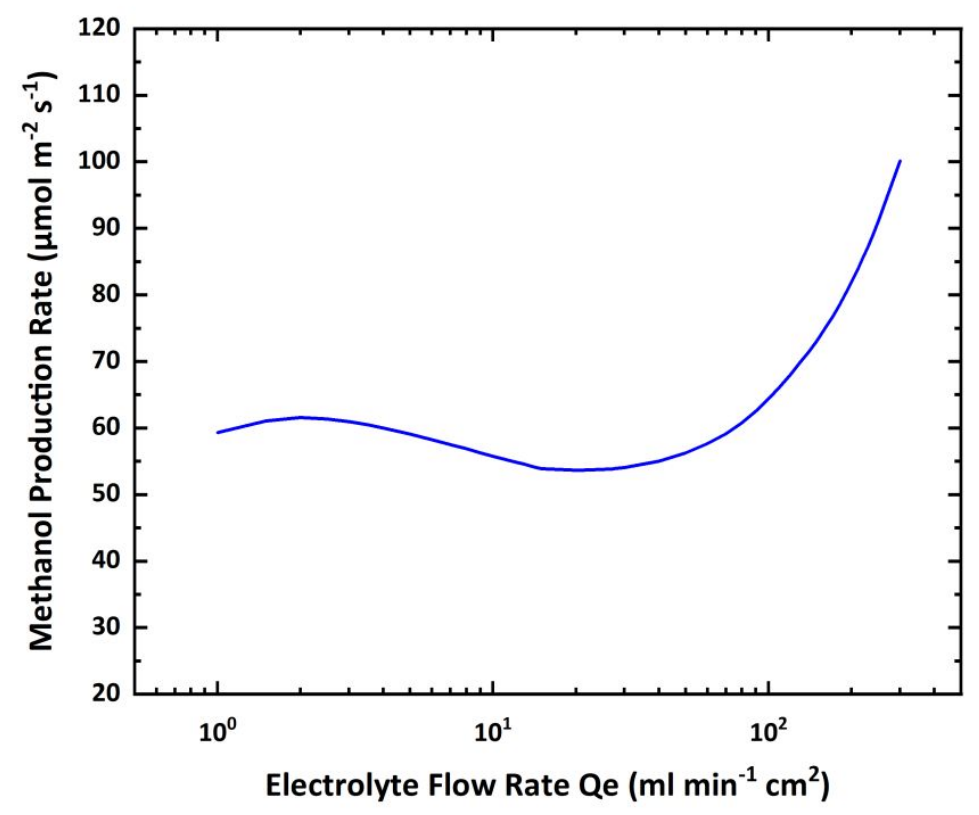

Fig. 5. Effect of electrolyte flow rate on $\mathrm{CH}_{3} \mathrm{OH}$ production rate, at constant $\mathrm{j}=10 \mathrm{~mA}$

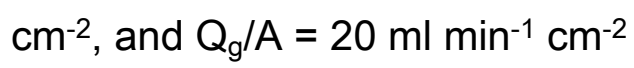

At low electrolyte flow rate, it is expected that the dominant force in the porous $C L$ is the capillary force, where $\mathrm{CO}_{2}$ will be available in the middle of the $\mathrm{CL}$ pores separated from the electrode surface by a layer of electrolyte. At this condition, the $\mathrm{CH}_{3} \mathrm{OH}$ production rate was relatively constant, as in Fig. 5 . However, as the electrolyte flow rate increase, it is expected that the capillary number will increase, elevating the possibility 
that a shift in the dominant force toward viscous forces at very high electrolyte flow rate.

At this condition, the production of $\mathrm{CH}_{3} \mathrm{OH}$ starts to increase rapidly. Hence, economic wise it is recommended to work at low electrolyte flow rate to obtain high concentrated liquid products, lower the operating cost, and avoid excessive electrolyte wastes. ${ }^{59}$

Combining the findings of the present research regarding the effect of increasing the $\mathrm{CO}_{2}$ gas flow rate, Fig. 4 , and electrolyte flow rate, Fig. 5 , it is believed that in the GDE based electrochemical cell, $\mathrm{CO}_{2}$ needs to dissolve first in the aqueous phase for the reduction reaction to occur in agreement with Weng et al. ${ }^{18}$. However, at low electrolyte flow rate the presence of the $\mathrm{CO}_{2}$ as a gas phase is essential to improve the production rate.

\subsection{Effect of Feed $\mathrm{CO}_{2}$ Concentration}

Variable $\mathrm{CO}_{2}$ sources are available for the electrochemical reduction of $\mathrm{CO}_{2}$ to produce $\mathrm{CH}_{3} \mathrm{OH}$. Though these sources are not of high purity. In addition, the concentration of $\mathrm{CO}_{2}$ varies from one source to another. Hence, it is important to study the effect of 
variation in the concentration of $\mathrm{CO}_{2}$ in the feed stream on the amount of $\mathrm{CH}_{3} \mathrm{OH}$ that could be produced by the electrochemical reduction of $\mathrm{CO}_{2}$.

In practice, the purification cost of $\mathrm{CO}_{2}$ stream increases with the increase in the degree of purity required, this means that obtaining a $100 \%$ pure $\mathrm{CO}_{2}$ stream is too expensive which will add up to the cost of the overall process. On the other hand, a stream of $\mathrm{CO}_{2}$ of purity $90 \%$ and lower can be obtained at a relatively reasonable price. The model was used to investigate the effect of increasing the concentration of $\mathrm{CO}_{2}$ on the production rate and $\mathrm{FE}$ of $\mathrm{CH}_{3} \mathrm{OH}$ at various applied current density and various gas flow rate within the optimum range. According to Fig. 6 and 7 , as the $\mathrm{CO}_{2}$ concentration increases the production rate and $\mathrm{FE}$ of $\mathrm{CH}_{3} \mathrm{OH}$ increases, however, a plateau is reached at $\mathrm{CO}_{2}$ concentration of nearly $90 \%$. In addition, as the $\mathrm{CO}_{2}$ concentration increases, the effect of increasing the gas flow rate and the applied current density increases. Hence, working at $90 \%$ or slightly lower $\mathrm{CO}_{2}$ concentration at optimum values of applied current density and gas flow rate is recommended from the economic point of view. 


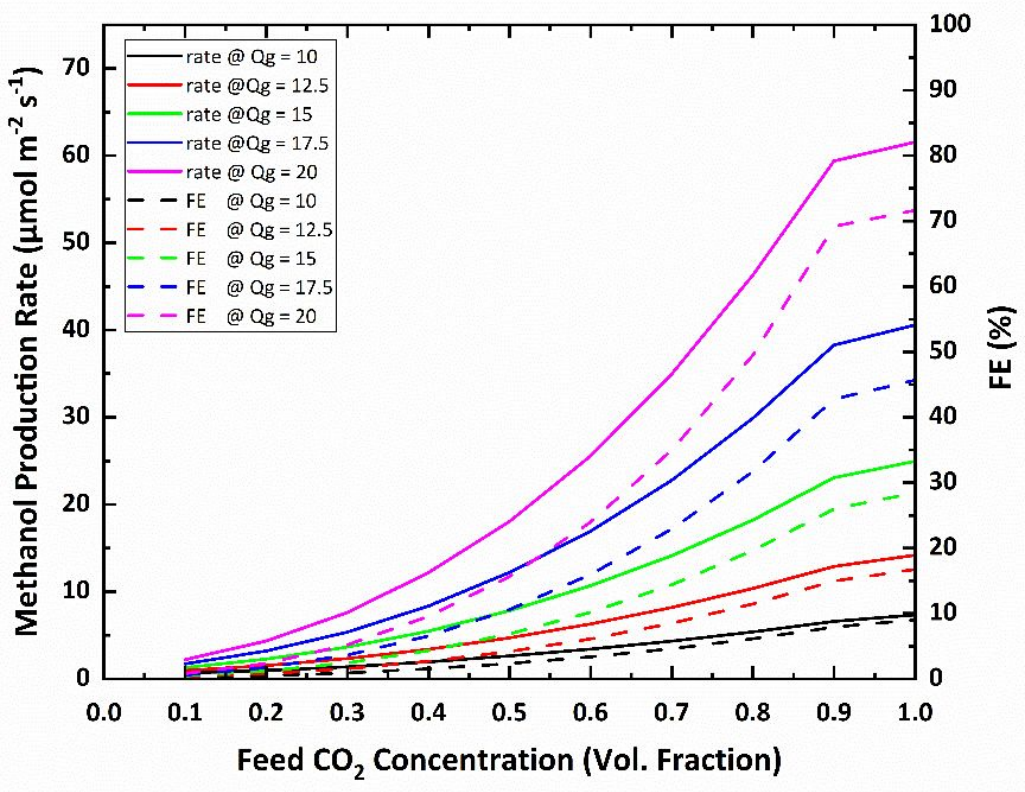

Fig. 6. Effect of feed $\mathrm{CO}_{2}$ concentration on the production rate and $\mathrm{FE}$ of $\mathrm{CH}_{3} \mathrm{OH}$ as a function of gas flow rate $\left(Q_{g}, \mathrm{ml} \mathrm{min}^{-1} \mathrm{~cm}^{-2}\right)$, at constant $\mathrm{j}=10 \mathrm{~mA} \mathrm{~cm}-2$, and $Q_{e} / A=2 \mathrm{ml}$ $\mathrm{min}^{-1} \mathrm{~cm}^{-2}$

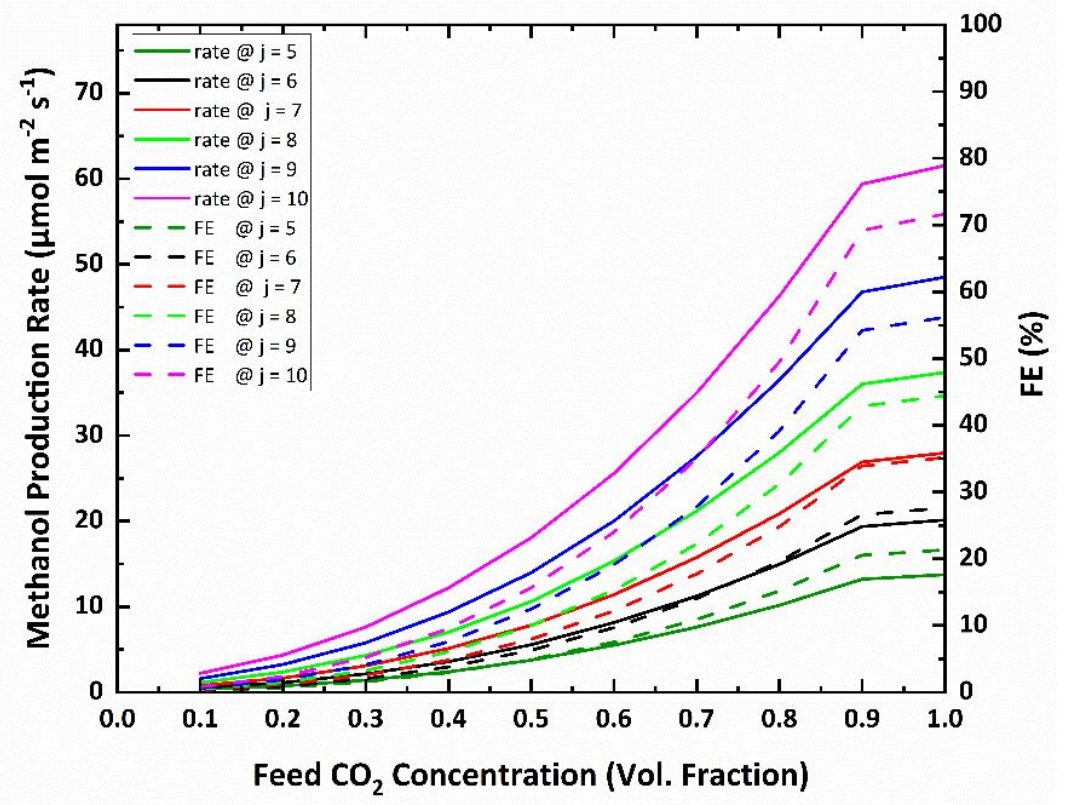


Fig. 7. Effect of feed $\mathrm{CO}_{2}$ concentration on the production rate and $\mathrm{FE}$ of $\mathrm{CH}_{3} \mathrm{OH}$ as a function of applied current density $\left(\mathrm{j}, \mathrm{mA} \mathrm{cm}{ }^{-2}\right)$ at constant $Q_{g}=20 \mathrm{ml} \mathrm{min}^{-1} \mathrm{~cm}^{-2}$, and

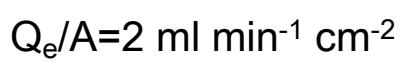

\subsection{Product Distribution}

Fig. 8 illustrates product distribution through the cell. $\mathrm{CH}_{3} \mathrm{OH}$, as well as $\mathrm{C}_{2} \mathrm{H}_{5} \mathrm{OH}$, was found to be concentrated inside the $C L$ and around the CL-catholyte interface, with zero concentration elsewhere. It is clear that $\mathrm{CH}_{3} \mathrm{OH}$ did not cross the membrane. $\mathrm{CH}_{3} \mathrm{OH}$ and $\mathrm{C}_{2} \mathrm{H}_{5} \mathrm{OH}$ are produced at the cathode with different rates depending on the parameters in their kinetic rate equations, eqs (42) and (43).

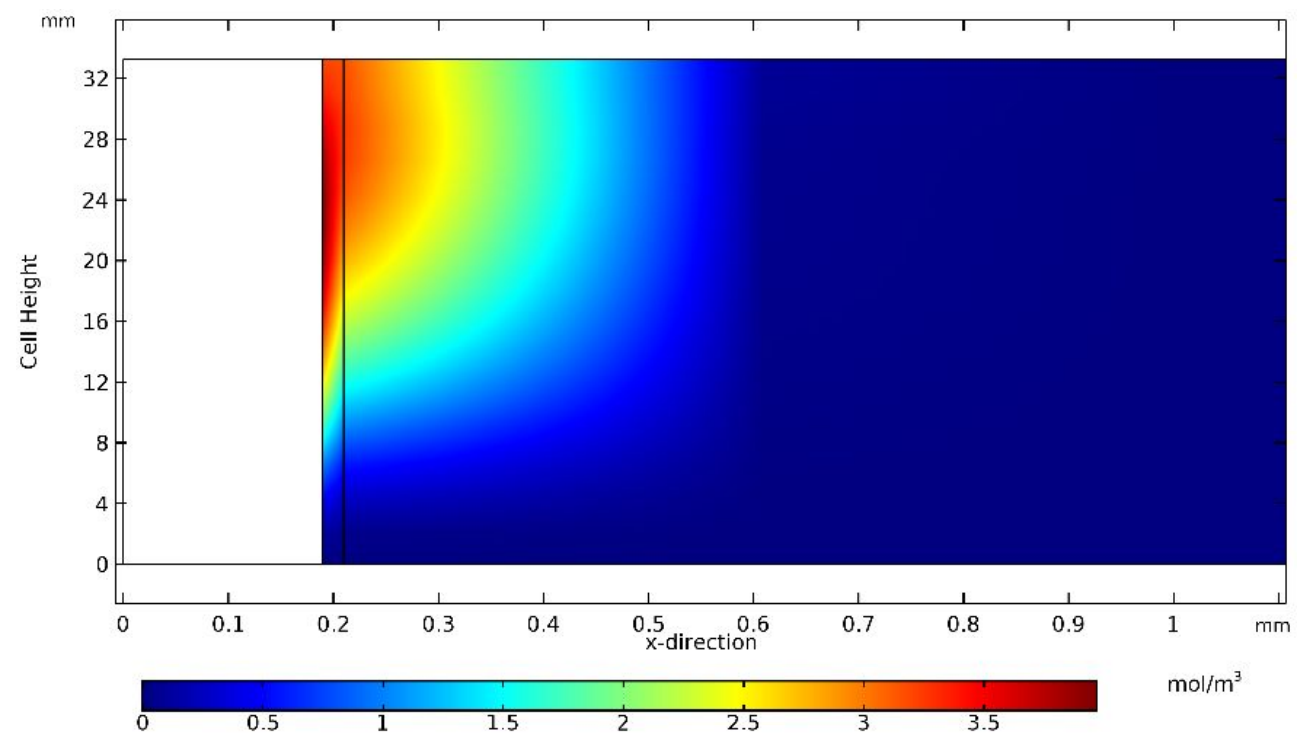


Fig. 8. Distribution of the concentration of $\mathrm{CH}_{3} \mathrm{OH}$, in $\mathrm{mol} \mathrm{m}^{-3}$, through the $\mathrm{CL}$ and catholyte

In addition, Fig. 9 shows the production fluxes of the different species across the cathodic $\mathrm{CL}$. It is clear that the fluxes of $\mathrm{CH}_{3} \mathrm{OH}$ and $\mathrm{C}_{2} \mathrm{H}_{5} \mathrm{OH}$ are function of the concentration of the reactants at the surface of the cathode, so their production rate reaches its maximum value at the center of the cell entrance. On the other hand, the rate of $\mathrm{H}_{2}$ production, shown in Fig. 9 , is independent of the cathode position because it is not affected by the availability of the reacting $\mathrm{CO}_{2}$. In the electrochemical cell, the applied current to the system was partially consumed by water reduction reaction rather than $\mathrm{CO}_{2}$ reduction so, $\mathrm{H}_{2}$ is produced continuously. 


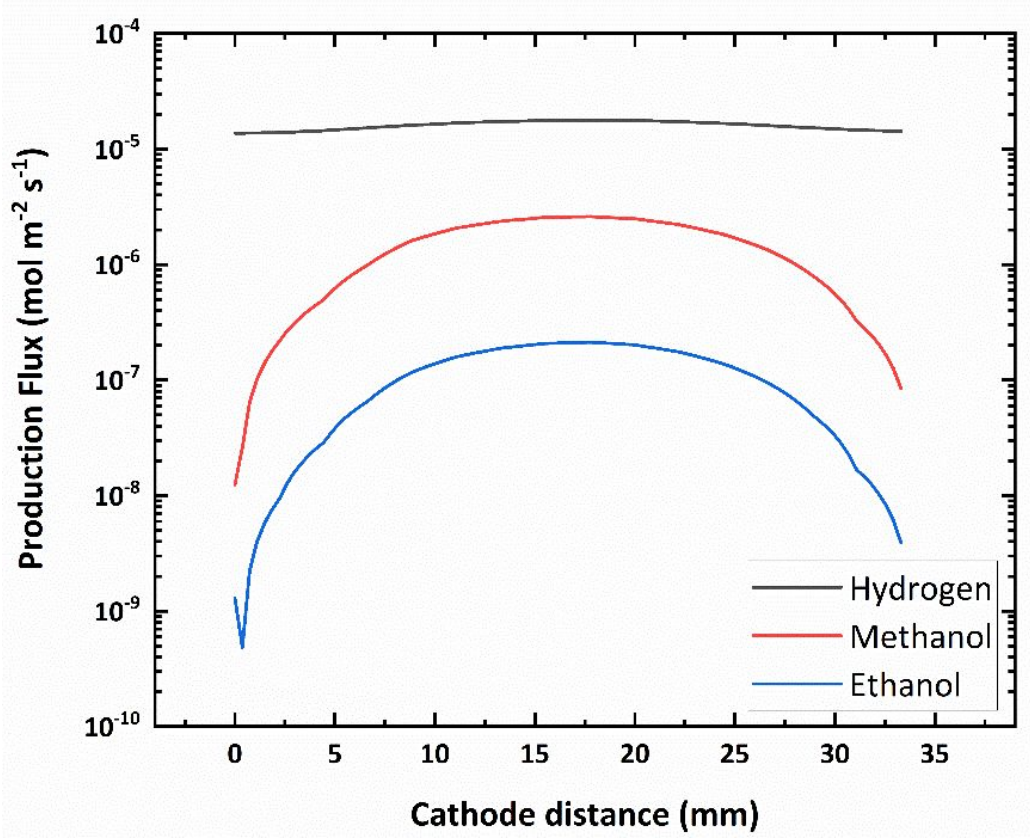

Fig. 9. The distribution of production flux of hydrogen, $\mathrm{CH}_{3} \mathrm{OH}$, and $\mathrm{C}_{2} \mathrm{H}_{5} \mathrm{OH}$ across the cathodic catalyst layer.

\section{Limitations of the Developed Model}

As far as we can tell, the present model is the first in investigating the role of GDEs in the $\mathrm{CO}_{2}$ electrochemical reduction into $\mathrm{CH}_{3} \mathrm{OH}$, where the exchange current density was expressed as a function of the operating conditions. However, the model still has some limitations restricting its ability to predict the effect of other process variables. These limitations can be summarized as follows: 
- The model cannot capture the variation of system selectivity with the change in system conditions.

- The distribution of reactants over the catalyst active sites cannot be determined accurately which introduces some uncertainty in the estimated parameters.

- The variation of saturation fraction in the CL with the change in the gas and electrolyte flow rate was neglected in the model. This limited the capabilities of the model to fully express the effect of flow rate variation on the system.

- Assuming one-phase flow hindered the model to predict the possibility of electrolyte penetration by the undissolved $\mathrm{CO}_{2}$ gas or the production of $\mathrm{H}_{2}$ in the gas phase.

Accordingly, these points could be considered as a recommendation for future development of a continuous $\mathrm{CO}_{2}$ electrochemical reduction model for the production of $\mathrm{CH}_{3} \mathrm{OH}$ and other products.

\section{Conclusion}


In this study, a mathematical model was developed for a continuous $\mathrm{CO}_{2}$ electrochemical reduction cell for the production of $\mathrm{CH}_{3} \mathrm{OH}$, inside a filter-press electrochemical cell, equipped with $\mathrm{Cu}_{2} \mathrm{O} / \mathrm{ZnO}$-based $\mathrm{GDE}$, in $0.5 \mathrm{M} \mathrm{KHCO}_{3}$ aqueous solution, under ambient conditions. It incorporated charge, mass and momentum transport with electrode kinetics, and considered the equilibrium reactions between the electrolyte species. Experiments were conducted using a relevant setup to validate the model. The model demonstrated the effect of key variables on production rate and faradaic efficiency. It was found that:

- The simulation results were in good agreement with the experimental results, with an average error of $6 \%$.

- The production rate and the faradaic efficiency of both $\mathrm{CH}_{3} \mathrm{OH}$ and $\mathrm{C}_{2} \mathrm{H}_{5} \mathrm{OH}$ increase with the increase in current density up to a value of $9 \mathrm{~mA} \mathrm{~cm}^{-2}$. No further improvement in the $\mathrm{CH}_{3} \mathrm{OH}$ production rate above $50 \mu \mathrm{mol} \mathrm{m} \mathrm{m}^{-2} \mathrm{~s}^{-1}$ was obtained.

- $\mathrm{Cu}_{2} \mathrm{O}-\mathrm{ZnO}$ GDEs are more selective to $\mathrm{CH}_{3} \mathrm{OH}$ formation over $\mathrm{C}_{2} \mathrm{H}_{5} \mathrm{OH} ; 56 \%$ faradaic efficiency of $\mathrm{CH}_{3} \mathrm{OH}$ was obtained compared to $8 \%$ maximum for $\mathrm{C}_{2} \mathrm{H}_{5} \mathrm{OH}$. 
- As the flow rate of feed $\mathrm{CO}_{2}$ increases, the production rate and the faradaic efficiency of $\mathrm{CH}_{3} \mathrm{OH}$ increases up to an optimum value of $17.5 \mathrm{ml} \mathrm{min}^{-1} \mathrm{~cm}^{-2}$ after which the production rate and the selectivity will drop.

- Increasing the flow rate of the electrolyte did not affect $\mathrm{CH}_{3} \mathrm{OH}$ production at low flow rate. Only at very high electrolyte flow rate, the production of $\mathrm{CH}_{3} \mathrm{OH}$ started to increase rapidly.

- Working at low electrolyte flow rate is economic and more practical.

- At low electrolyte flow rate, the presence of the $\mathrm{CO}_{2}$ as a gas phase is essential to improve the production rate.

- From the economic point of view, it is recommended to use a gas stream of $90 \%$ or slightly lower $\mathrm{CO}_{2}$ concentration at optimum values of applied current density and gas flow rate.

As far as we can tell, this work is the first to model the GDE systems for $\mathrm{CO}_{2}$ reduction into $\mathrm{CH}_{3} \mathrm{OH}$. In addition, it is the first $2 \mathrm{D}$ model that deals with the catalyst layer as a domain not as an interface, and the first to conclude an empirical relationship between the exchange current density and the operating conditions. In sum, the insights presented 
in this model can be used as a guide for an effective design of GDE-based electrochemical cells, and as a step for process scale-up and optimization.

\section{AUTHOR INFORMATION}

\section{Corresponding Author}

*Tel.: +201207370644. E-mail: omniaelshafie737@gmail.com

ORCID

Omnia A. El-Shafie: 0000-0003-0735-6758

Notes

The authors declare no competing financial interest.

\section{ACKNOWLEDGMENT}

J. Albo gratefully acknowledges the financial support from the Spanish Ministry of Economy and Competitiveness (MINECO) under Ramón y Cajal programme (RYC-201517080). 


\section{List of symbols}

\section{Roman}

$A \quad$ Electrode geometric area, $\mathrm{m}^{2}$

$a_{i} \quad$ Activity of species $\mathrm{i}, \mathrm{mol} \mathrm{m} \mathrm{m}^{-3}$

$c_{i} \quad$ Concentration of species i, $\mathrm{mol} \mathrm{m}^{-3}$

$c_{\text {ref }} \quad$ Reference concentration, $\mathrm{mol} \mathrm{m}^{-3}$

$D_{i} \quad$ Diffusivity of species $\mathrm{i}, \mathrm{m}^{2} \mathrm{~s}^{-1}$

$E^{0} \quad$ Reversible electrode potential, $\mathrm{V}$

$\boldsymbol{F}_{\boldsymbol{v}} \quad$ Volume force vector, $\mathrm{N} \mathrm{m}^{-3}$

F Faraday's Constant, 96,487 $\mathrm{C} \mathrm{mol}^{-1}$

$F E \quad$ Faradaic Efficiency, \%

$g \quad$ Gravitational acceleration, $\mathrm{m}^{2} \mathrm{~s}^{-1}$

H Cell height, $\mathrm{m}$

$H_{i} \quad$ Henry constant of species i, mol m $\mathrm{m}^{-3} \mathrm{~Pa}^{-1}$

$i_{\text {loc }} \quad$ Local current density, $\mathrm{A} \mathrm{m}^{-2}$

$i_{0, k} \quad$ Exchange current density of reaction $\mathrm{k}, \mathrm{A} \mathrm{m}^{-2}$

I Identity tensor

$j \quad$ Current Density, $\mathrm{A} \mathrm{m}^{-2}$

$K \quad$ Permeability, $\mathrm{m}^{2}$

$L \quad$ Thickness of each electrolyte channel, mm

$M_{i} \quad$ Molecular weight of species i, $\mathrm{kg} \mathrm{mol}^{-1}$ 
2

$\boldsymbol{N}_{\boldsymbol{i}} \quad$ Flux vector of species $i, \mathrm{~mol} \mathrm{~m}^{-2} \mathrm{~s}^{-1}$

$P \quad$ Atmospheric pressure

$Q \quad$ Flow rate, $\mathrm{m}^{3} \mathrm{~s}^{-1}$

$r \quad$ radius, $\mathrm{m}$

$R \quad$ Gas constant, $\mathrm{J} \mathrm{mol}^{-1} \mathrm{~K}^{-1}$

$\boldsymbol{R}_{\boldsymbol{i}} \quad$ Rate of production or consumption for species $i, \mathrm{~mol} \mathrm{~m}^{-3} \mathrm{~s}^{-1}$

$S \quad$ Saturation

$T \quad$ Temperature, $\mathrm{K}$

$\boldsymbol{u} \quad$ Velocity vector, $\mathrm{m} \mathrm{s}^{-1}$

$u_{m, i} \quad$ ionic mobility of species $\mathrm{i}, \mathrm{mol} \mathrm{s} \mathrm{kg}^{-1}$

$x_{j} \quad$ thickness of domain $\mathrm{j}, \mathrm{m}$

$Y_{j} \quad$ mole fraction of species i

W $\quad$ Cell width, $\mathrm{m}$

Z Number of electrons transferred

$Z_{i} \quad$ Charge number of species i

\section{Greek}

$\alpha \quad$ Charge transfer coefficient

$\delta \quad$ thickness, $\mathrm{m}$

$\eta \quad$ Overpotential, $\mathrm{V}$

$\mu \quad$ Viscosity

$\rho \quad$ Density, $\mathrm{Kg} \mathrm{m}^{-3}$

$\varepsilon \quad$ Porosity 


$\begin{array}{ll}\sigma & \text { Electric conductivity, } \mathrm{S} \mathrm{m}^{-1} \\ \varphi & \text { Potential, } \mathrm{V} \\ \tau & \text { Tortuosity } \\ v & \text { Stoichiometric coefficient } \\ v_{i} & \text { Diffusion Volume of species i } \\ \omega_{i} & \text { Mass fraction of species } i\end{array}$

\section{Subscript}

$\begin{array}{ll}a & \text { Anode } \\ a b s & \text { Absorbed } \\ a q & \text { Aqueous phase } \\ a p p & \text { Applied } \\ \mathrm{B} & \text { Bulk } \\ \mathrm{C} & \text { Cathode } \\ \mathrm{CO}_{2} & \text { Carbon dioxide } \\ \mathrm{CO}_{3}^{-2} & \text { Carbonate ion } \\ \mathrm{Cp} & \text { Carbon paper } \\ \mathrm{CL} & \text { Catalyst layer } \\ \mathrm{D} & \text { Donnan } \\ e & \text { Electrolyte } \\ e f f & \text { Effective } \\ e x t & \text { External }\end{array}$




\begin{tabular}{|c|c|}
\hline$g$ & Gas \\
\hline$G D E$ & Gas diffusion electrode \\
\hline$G D L$ & Gas diffusion layer \\
\hline$H^{+}$ & Hydrogen ion \\
\hline $\begin{array}{l}H C \\
O_{3}^{-1}\end{array}$ & Bicarbonate ion \\
\hline $\mathrm{H}_{2} \mathrm{O}$ & Water \\
\hline$i$ & Species \\
\hline in & Inlet \\
\hline$K^{+}$ & Potassium ion \\
\hline$l$ & Liquid phase \\
\hline$m$ & Membrane \\
\hline$O$ & Oxidized \\
\hline $\mathrm{OH}^{+}$ & Hydroxyl ion \\
\hline $\mathrm{O}_{2}$ & Oxygen \\
\hline$p$ & particle \\
\hline$R$ & Reduced \\
\hline ref & Reference value \\
\hline$S$ & Surface or solid phase \\
\hline$t f$ & Thin film \\
\hline
\end{tabular}

\section{Superscript}

exp. Experimental 
num. Numerical

Transpose

\section{REFERENCES}

(1) Song, C. Global Challenges and Strategies for Control, Conversion and Utilization of CO2 for Sustainable Development Involving Energy, Catalysis, Adsorption and Chemical Processing. Catalysis Today 2006, $115 \quad$ (1-4), 2-32. https://doi.org/10.1016/j.cattod.2006.02.029.

(2) Friedlingstein, P.; Andrew, R. M.; Rogelj, J.; Peters, G. P.; Canadell, J. G.; Knutti, R.; Luderer, G.; Raupach, M. R.; Schaeffer, M.; van Vuuren, D. P.; et al. Persistent Growth of CO2 Emissions and Implications for Reaching Climate Targets. Nature Geoscience 2014, 7(10), 709-715. https://doi.org/10.1038/ngeo2248.

(3) Qiao, J.; Liu, Y.; Zhan, J. Electrochemical Reduction of Carbon Dioxide. Fundamentals and Technologies; 2016.

(4) Centi, G.; Perathoner, S. Opportunities and Prospects in the Chemical Recycling 
of Carbon Dioxide to Fuels. Catalysis Today 2009, 148 (3-4), 191-205.

https://doi.org/10.1016/j.cattod.2009.07.075.

(5) Centi, G.; Quadrelli, E. A.; Perathoner, S. Catalysis for CO2 Conversion: A Key

Technology for Rapid Introduction of Renewable Energy in the Value Chain of

Chemical Industries. Energy and Environmental Science 2013, 6 (6), 1711-1731.

https://doi.org/10.1039/c3ee00056g.

(6) Albo, J.; Alvarez-Guerra, M.; Castaño, P.; Irabien, A. Towards the Electrochemical

Conversion of Carbon Dioxide into Methanol. Green Chemistry 2015, 17(4), 2304-

2324. https://doi.org/10.1039/C4GC02453B.

(7) Rabiee, A.; Nematollahi, D. Pyridinium-Facilitated CO 2 Electroreduction on $\mathrm{Pt}$

Nanowire: Enhanced Electrochemical Performance in $\mathrm{CO} 2$ Conversion.

Environmental Progress \& Sustainable Energy 2019, 38 (1), 112-117.

https://doi.org/10.1002/ep.12975.

(8) Wang, R.; Kapteijn, F.; Gascon, J. Engineering Metal-Organic Frameworks for the

Electrochemical Reduction of CO 2: A Minireview. Chemistry - An Asian Journal 
2019, 14 (20), 3452-3461. https://doi.org/10.1002/asia.201900710.

(9) Malik, K.; Singh, S.; Basu, S.; Verma, A. Electrochemical Reduction of CO 2 for Synthesis of Green Fuel. Wiley Interdisciplinary Reviews: Energy and Environment 2017, 6 (4), e244. https://doi.org/10.1002/wene.244.

(10) Kaneco, S.; Hiei, N.; Xing, Y.; Katsumata, H.; Ohnishi, H.; Suzuki, T.; Ohta, K. Electrochemical Conversion of Carbon Dioxide to Methane in Aqueous NaHCO3 Solution at Less than 273 K. Electrochimica Acta 2002, 48 (1), 51-55. https://doi.org/10.1016/S0013-4686(02)00550-9.

(11) Morrison, A. R. T.; van Beusekom, V.; Ramdin, M.; van den Broeke, L. J. P.; Vlugt, T. J. H.; de Jong, W. Modeling the Electrochemical Conversion of Carbon Dioxide to Formic Acid or Formate at Elevated Pressures. Journal of The Electrochemical Society 2019, 166 (4), E77-E86. https://doi.org/10.1149/2.0121904jes.

(12) Hara, K.; Kudo, A.; Sakata, T.; Watanabe, M. High Efficiency Electrochemical Reduction of Carbon Dioxide under High Pressure on a Gas Diffusion Electrode Containing Pt Catalysts. Journal of The Electrochemical Society 1995, 142 (4), 
L57-L59. https://doi.org/10.1149/1.2044182.

(13) Piontek, S.; junge Puring, K.; Siegmund, D.; Smialkowski, M.; Sinev, I.; Tetzlaff, D.;

Roldan Cuenya, B.; Apfel, U.-P. Bio-Inspired Design: Bulk Iron-Nickel Sulfide

Allows for Efficient Solvent-Dependent CO 2 Reduction. Chemical Science 2019, 10 (4), 1075-1081. https://doi.org/10.1039/C8SC03555E.

(14) Aeshala, L. M.; Rahman, S. U.; Verma, A. Effect of Solid Polymer Electrolyte on Electrochemical Reduction of CO2. Separation and Purification Technology 2012, 94, 131-137. https://doi.org/10.1016/j.seppur.2011.12.030.

(15) Sebastián, D.; Palella, A.; Baglio, V.; Spadaro, L.; Siracusano, S.; Negro, P.; Niccoli, F.; Aricò, A. S. CO2 Reduction to Alcohols in a Polymer Electrolyte Membrane Co-Electrolysis Cell Operating at Low Potentials. Electrochimica Acta 2017, 241, 28-40. https://doi.org/10.1016/j.electacta.2017.04.119.

(16) Bernardi, D. M. A Mathematical Model of the Solid-Polymer-Electrolyte Fuel Cell. Journal of The Electrochemical Society 1992, 139 (9), 2477. https://doi.org/10.1149/1.2221251. 
(17) Albo, J.; Irabien, A. Cu2O-Loaded Gas Diffusion Electrodes for the Continuous Electrochemical Reduction of CO2 to Methanol. Journal of Catalysis 2016, 343, 232-239. https://doi.org/10.1016/j.jcat.2015.11.014.

(18) Weng, L. C.; Bell, A. T.; Weber, A. Z. Modeling Gas-Diffusion Electrodes for CO2 Reduction. Physical Chemistry Chemical Physics 2018, 20 (25), 16973-16984. https://doi.org/10.1039/c8cp01319e.

(19) Kopljar, D.; Inan, A.; Vindayer, P.; Wagner, N.; Klemm, E. Electrochemical Reduction of $\mathrm{CO} 2$ to Formate at High Current Density Using Gas Diffusion Electrodes. Journal of Applied Electrochemistry 2014, 44 (10), 1107-1116. https://doi.org/10.1007/s10800-014-0731-x.

(20) El-kharouf, A.; Mason, T. J.; Brett, D. J. L.; Pollet, B. G. Ex-Situ Characterisation of Gas Diffusion Layers for Proton Exchange Membrane Fuel Cells. Journal of Power Sources 2012, 218, 393-404. https://doi.org/https://doi.org/10.1016/j.jpowsour.2012.06.099.

(21) Weng, L.-C.; Bell, A. T.; Weber, A. Z. Modeling Gas-Diffusion Electrodes for CO 2 
Reduction. Physical Chemistry Chemical Physics 2018, 20 (25), 16973-16984.

https://doi.org/10.1039/C8CP01319E.

(22) Park, S.; Lee, J.-W.; Popov, B. N. A Review of Gas Diffusion Layer in PEM Fuel Cells: Materials and Designs. International Journal of Hydrogen Energy 2012, 37 (7), 5850-5865. https://doi.org/10.1016/j.ijhydene.2011.12.148.

(23) Cook, R. L.; MacDuff, R. C.; Sammells, A. F. High Rate Gas Phase CO2 Reduction to Ethylene and Methane Using Gas Diffusion Electrodes. Journal of The Electrochemical Society 1990, 137(2), 607. https://doi.org/10.1149/1.2086515.

(24) Wu, K.; Birgersson, E.; Kim, B.; Kenis, P. J. A.; Karimi, I. A. Modeling and Experimental Validation of Electrochemical Reduction of $\mathrm{CO} 2$ to $\mathrm{CO}$ in a Microfluidic Cell. Journal of The Electrochemical Society 2015, 162 (1), F23-F32. https://doi.org/10.1149/2.1021414jes.

(25) Yano, H.; Shirai, F.; Nakayama, M.; Ogura, K. Efficient Electrochemical Conversion of CO2to $\mathrm{CO}, \mathrm{C} 2 \mathrm{H} 4$ and $\mathrm{CH} 4$ at a Three-Phase Interface on a Cu Net Electrode in Acidic Solution. Journal of Electroanalytical Chemistry 2002, 519 (1-2), 93-100. 
https://doi.org/10.1016/S0022-0728(01)00729-X.

(26) Kortlever, R.; Shen, J.; Schouten, K. J. P.; Calle-Vallejo, F.; Koper, M. T. M.

Catalysts and Reaction Pathways for the Electrochemical Reduction of Carbon

Dioxide. Journal of Physical Chemistry Letters 2015, 6 (20), 4073-4082.

https://doi.org/10.1021/acs.jpclett.5b01559.

(27) Ma, S.; Luo, R.; Moniri, S.; Lan, Y.; Kenis, P. J. a. Efficient Electrochemical Flow

System with Improved Anode for the Conversion of $\mathrm{CO} 2$ to $\mathrm{CO}$. Journal of The

Electrochemical Society 2014, $161 \quad(10), \quad$ F1124-F1131.

https://doi.org/10.1149/2.1201410jes.

(28) Larrazábal, G. O.; Martín, A. J.; Pérez-Ramírez, J. Building Blocks for High

Performance in Electrocatalytic CO 2 Reduction: Materials, Optimization

Strategies, and Device Engineering. The Journal of Physical Chemistry Letters

2017, 8(16), 3933-3944. https://doi.org/10.1021/acs.jpclett.7b01380.

(29) Alvarez-Guerra, M.; Quintanilla, S.; Irabien, A. Conversion of Carbon Dioxide into

Formate Using a Continuous Electrochemical Reduction Process in a Lead 
Cathode. Chemical Engineering Journal 2012, 207-208, 278-284. https://doi.org/10.1016/j.cej.2012.06.099.

(30) Agarwal, A. S.; Zhai, Y.; Hill, D.; Sridhar, N. The Electrochemical Reduction of Carbon Dioxide to Formate/Formic Acid: Engineering and Economic Feasibility. ChemSusChem 2011, 4 (9), 1301-1310. https://doi.org/10.1002/cssc.201100220.

(31) Chi, D.; Yang, H.; Du, Y.; Lv, T.; Sui, G.; Wang, H.; Lu, J. Morphology-Controlled CuO Nanoparticles for Electroreduction of CO 2 to Ethanol. RSC Advances 2014, 4 (70), 37329-37332. https://doi.org/10.1039/c4ra05415f.

(32) Albo, J.; Sáez, A.; Solla-Gullón, J.; Montiel, V.; Irabien, A. Production of Methanol from $\mathrm{CO} 2$ Electroreduction at $\mathrm{Cu} 2 \mathrm{O}$ and $\mathrm{Cu} 2 \mathrm{O} / \mathrm{ZnO}-\mathrm{Based}$ Electrodes in Aqueous Solution. Applied Catalysis B: Environmental 2015, 176-177 (MAY), 709-717. https://doi.org/10.1016/j.apcatb.2015.04.055.

(33) Albo, J.; Irabien, A. Cu2O-Loaded Gas Diffusion Electrodes for the Continuous Electrochemical Reduction of CO2 to Methanol. Journal of Catalysis 2016, 343, 232-239. https://doi.org/10.1016/j.jcat.2015.11.014. 
(34) Albo, J.; Beobide, G.; Castaño, P.; Irabien, A. Methanol Electrosynthesis from CO

2 at $\mathrm{Cu} 2 \mathrm{O} / \mathrm{ZnO}$ Prompted by Pyridine-Based Aqueous Solutions. Journal of CO2

Utilization 2017, 18, 164-172. https://doi.org/10.1016/j.jcou.2017.02.003.

(35) Andrews, E.; Ren, M.; Wang, F.; Zhang, Z.; Sprunger, P.; Kurtz, R.; Flake, J.

Electrochemical Reduction of $\mathrm{CO} 2$ at $\mathrm{Cu}$ Nanocluster / (100) ZnO Electrodes.

Journal of the Electrochemical Society 2013, 160 (11), H841-H846.

https://doi.org/10.1149/2.105311jes.

(36) Albo, J.; Perfecto-Irigaray, M.; Beobide, G.; Irabien, A. Cu/Bi Metal-Organic

Framework-Based Systems for an Enhanced Electrochemical Transformation of

CO2 to Alcohols. Journal of CO2 Utilization 2019, 33 (January), 157-165.

https://doi.org/10.1016/j.jcou.2019.05.025.

(37) Albo, J.; Vallejo, D.; Beobide, G.; Castillo, O.; Castaño, P.; Irabien, A. Copper-

Based Metal-Organic Porous Materials for CO 2 Electrocatalytic Reduction to Alcohols. ChemSusChem 2017, $10 \quad$ (6), 1100-1109.

https://doi.org/10.1002/cssc.201600693. 
(38) Kotb, Y.; Fateen, S.-E. K.; Albo, J.; Ismail, I. Modeling of a Microfluidic Electrochemical Cell for the Electro-Reduction of $\mathrm{CO} 2$ to $\mathrm{CH} 3 \mathrm{OH}$. Journal of The Electrochemical Society 2017, $164 \quad$ (13), E391-E400. https://doi.org/10.1149/2.0741713jes.

(39) Georgopoulou, C.; Jain, S.; Agarwal, A.; Rode, E.; Dimopoulos, G.; Sridhar, N.; Kakalis, N. On the Modelling of Multidisciplinary Electrochemical Systems with Application on the Electrochemical Conversion of CO2 to Formate/Formic Acid. Computers \& Chemical Engineering 2016, 93, 160-170. https://doi.org/10.1016/j.compchemeng.2016.06.012.

(40) Merino-Garcia, I.; Albo, J.; Irabien, A. Tailoring Gas-Phase CO 2 Electroreduction Selectivity to Hydrocarbons at Cu Nanoparticles. Nanotechnology 2018, 29 (1), 014001. https://doi.org/10.1088/1361-6528/aa994e.

(41) Zhang, B.; Ye, D.; Sui, P.-C.; Djilali, N.; Zhu, X. Computational Modeling of AirBreathing Microfluidic Fuel Cells with Flow-over and Flow-through Anodes. Journal of Power $\quad$ Sources $\quad 2014, \quad 259, \quad 15-24$. 
https://doi.org/10.1016/j.jpowsour.2014.02.076.

(42) Zenyuk, I. V.; Das, P. K.; Weber, A. Z. Understanding Impacts of Catalyst-Layer Thickness on Fuel-Cell Performance via Mathematical Modeling. Journal of The Electrochemical Society 2016, $163 \quad$ (7), $\quad$ F691-F703. https://doi.org/10.1149/2.1161607jes.

(43) Luo, G.; Ji, Y.; Wang, C.-Y.; Sinha, P. K. Modeling Liquid Water Transport in Gas Diffusion Layers by Topologically Equivalent Pore Network. Electrochimica Acta 2010, 55(19), 5332-5341. https://doi.org/10.1016/j.electacta.2010.04.078.

(44) El-Kharouf, A.; Mason, T. J.; Brett, D. J. L.; Pollet, B. G. Ex-Situ Characterisation of Gas Diffusion Layers for Proton Exchange Membrane Fuel Cells. Journal of $\begin{array}{llll}\text { Power Sources } & 2012, & 218,\end{array}$ https://doi.org/10.1016/j.jpowsour.2012.06.099.

(45) Shah, A. A.; Watt-Smith, M. J.; Walsh, F. C. A Dynamic Performance Model for Redox-Flow Batteries Involving Soluble Species. Electrochimica Acta 2008, 53 (27), 8087-8100. https://doi.org/10.1016/j.electacta.2008.05.067. 
(46) Fuller, E. N.; Schettler, P. D.; Giddings, J. C. NEW METHOD FOR PREDICTION

OF BINARY GAS-PHASE DIFFUSION COEFFICIENTS. Industrial \& Engineering

Chemistry 1966, 58(5), 18-27. https://doi.org/10.1021/ie50677a007.

(47) Gupta, N.; Gattrell, M.; MacDougall, B. Calculation for the Cathode Surface Concentrations in the Electrochemical Reduction of $\mathrm{CO} 2$ in $\mathrm{KHCO} 3$ Solutions. Journal of Applied Electrochemistry 2006, 36 (2), 161-172. https://doi.org/10.1007/s10800-005-9058-y.

(48) Newman, J.; Thomas-Alyea, K. E. Electrochemical Systems; The ECS Series of Texts and Monographs; Wiley, 2012.

(49) Cussler, E. L. Diffusion: Mass Transfer in Fluid Systems; Cambridge Series in Chemical Engineering; Cambridge University Press, 2009.

(50) P, D. CRC Handbook of Chemistry and Physics; CRC Press, 1992; Vol. 268. https://doi.org/10.1016/0022-2860(92)85083-s.

(51) Ubong, E. U.; Shi, Z.; Wang, X. Three-Dimensional Modeling and Experimental 
Study of a High Temperature PBI-Based PEM Fuel Cell. Journal of The Electrochemical Society2009, 156(10), B1276. https://doi.org/10.1149/1.3203309.

(52) Yang, W. W.; Zhao, T. S. A Two-Dimensional, Two-Phase Mass Transport Model for Liquid-Feed DMFCs. Electrochimica Acta 2007, 52 (20), 6125-6140. https://doi.org/10.1016/j.electacta.2007.03.069.

(53) Knehr, K. W.; Kumbur, E. C. Open Circuit Voltage of Vanadium Redox Flow Batteries: Discrepancy between Models and Experiments. Electrochemistry $\begin{array}{llll}\text { Communications } & \text { 2011, } & 13 & \text { 34), }\end{array}$ https://doi.org/10.1016/j.elecom.2011.01.020.

(54) Ni, M. An Electrochemical Model for Syngas Production by Co-Electrolysis of $\mathrm{H} 2 \mathrm{O}$ and CO2. Journal of Power Sources 2012, 202, 209-216. https://doi.org/10.1016/j.jpowsour.2011.11.080.

(55) Kuhl, K. P.; Cave, E. R.; Abram, D. N.; Jaramillo, T. F. New Insights into the Electrochemical Reduction of Carbon Dioxide on Metallic Copper Surfaces. Energy \& Environmental Science 2012, 5(5), 7050. https://doi.org/10.1039/c2ee21234j. 
(56) Verma, S.; Kim, B.; Jhong, H. R. M.; Ma, S.; Kenis, P. J. A. A Gross-Margin Model for Defining Technoeconomic Benchmarks in the Electroreduction of $\mathrm{CO} 2$. ChemSusChem 2016, No. 3, 1972-1979. https://doi.org/10.1002/cssc.201600394.

(57) Yoon, S. K.; Fichtl, G. W.; Kenis, P. J. A. Active Control of the Depletion Boundary Layers in Microfluidic Electrochemical Reactors. Lab on a Chip 2006, 6(12), 15161524. https://doi.org/10.1039/b609289f.

(58) Del Castillo, A.; Alvarez-Guerra, M.; Irabien, A. Continuous Electroreduction of CO 2 to Formate Using Sn Gas Diffusion Electrodes. AlChE Journal 2014, 60 (10), 3557-3564. https://doi.org/10.1002/aic.14544.

(59) Lu, X.; Leung, D. Y. C.; Wang, H.; Xuan, J. A High Performance Dual Electrolyte Microfluidic Reactor for the Utilization of CO 2. Applied Energy 2017, 194, 549-559. https://doi.org/10.1016/j.apenergy.2016.05.091.

\section{For Table of Contents Use Only}




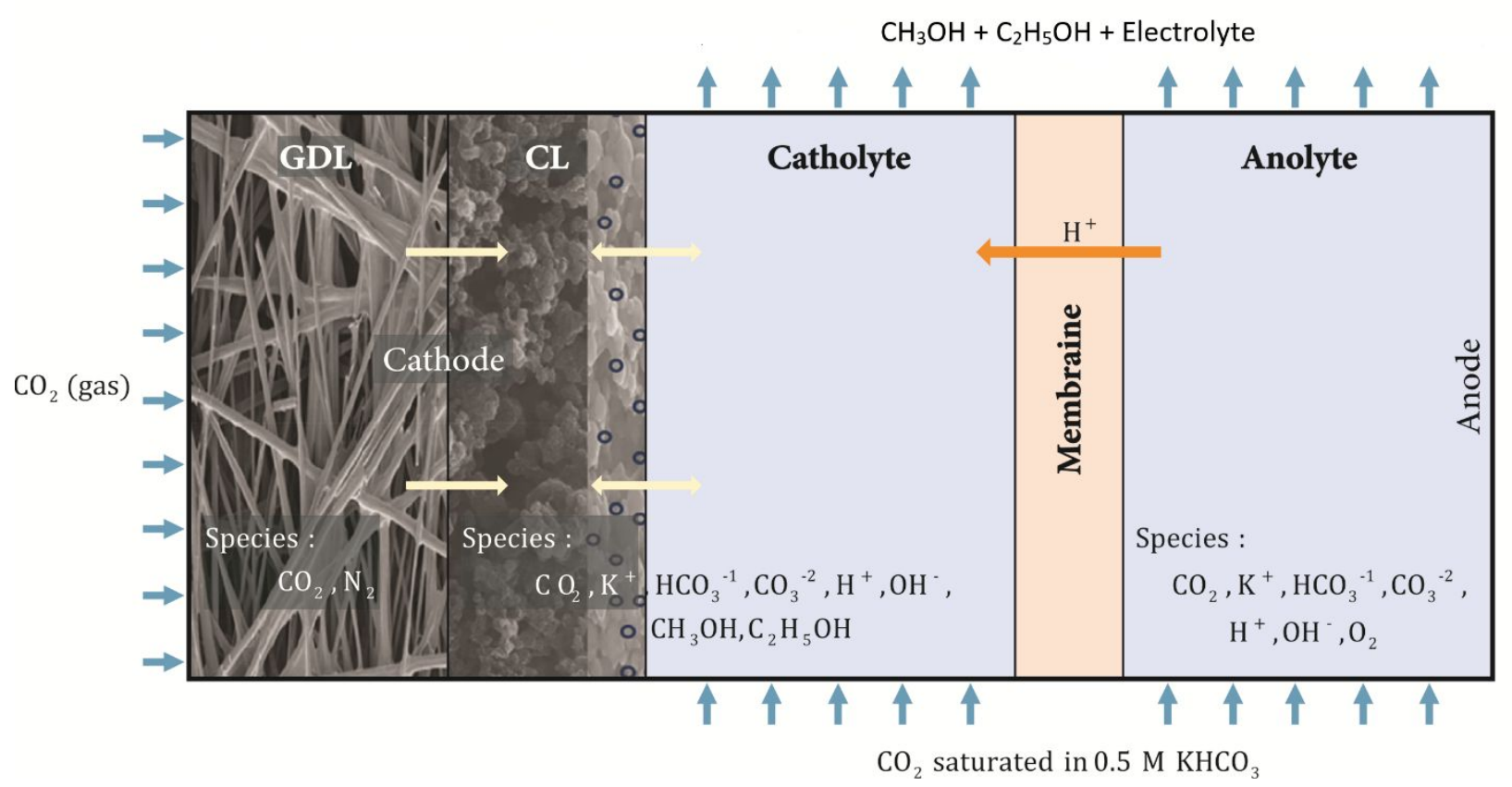

